MATTHEW MAZENIER

\title{
BATTLING THE BULGE: IS A BAN ON CHILDREN'S FOOD AND BEVERAGE ADVERTISING CONSISTENT WITH FREEDOM OF EXPRESSION?
}

\author{
LLM RESEARCH PAPER
}

LAWS520: CENSORSHIP AND FREEDOM OF EXPRESSION

\section{FACULTY OF LAW}

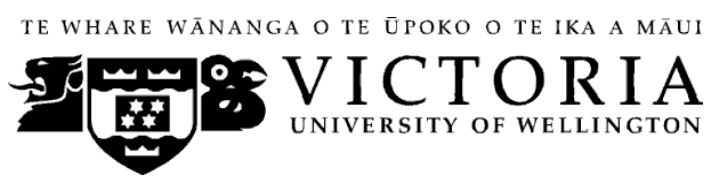

2014 


\section{Table of Contents}

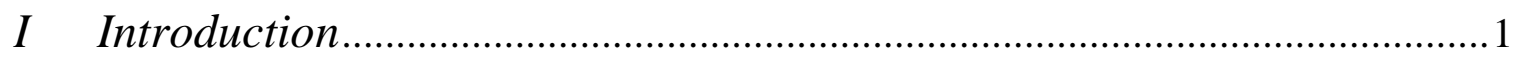

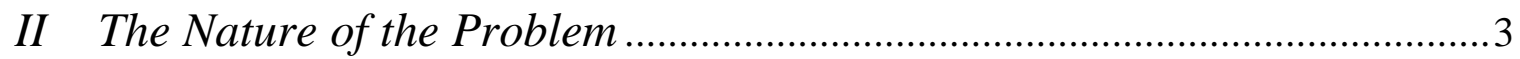

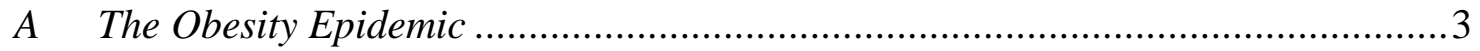

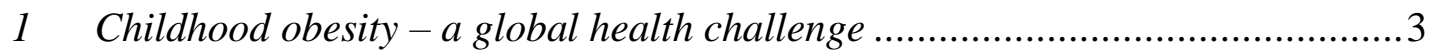

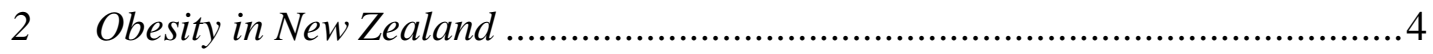

B The Advertising Connection - a Focus upon Children .......................................

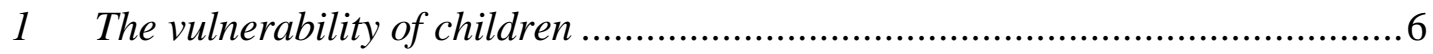

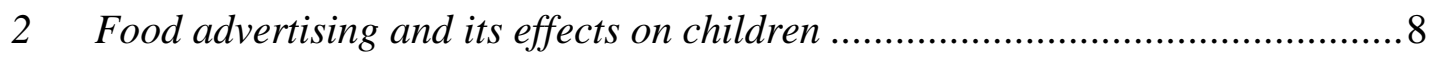

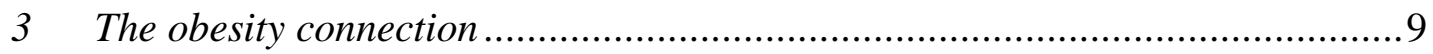

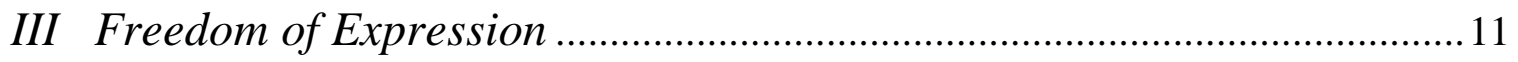

A Freedom of Expression and the Concept of Commercial Expression ...................11

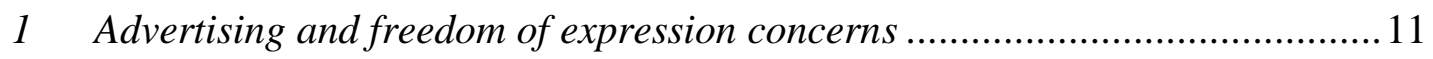

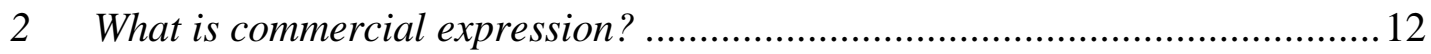

$B \quad$ The Argument for the Constitutional Protection of Commercial Expression ....... 14

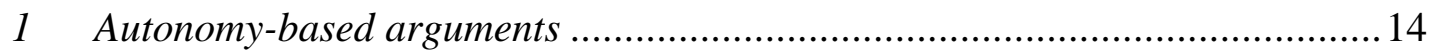

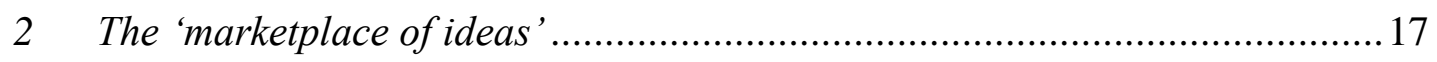

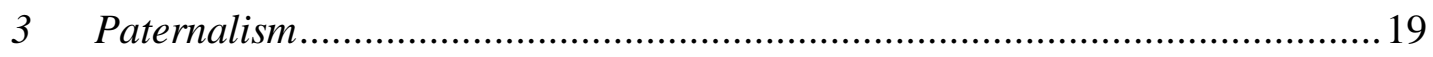

C Comparative Approaches to the Commercial Expression Doctrine .......................20

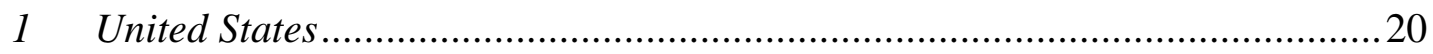

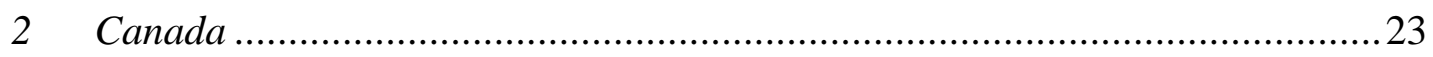

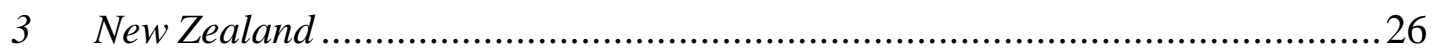

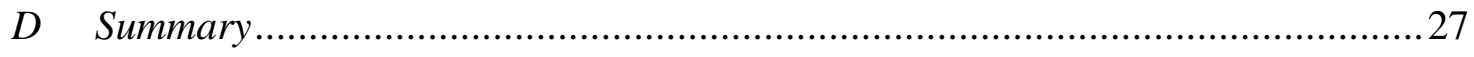

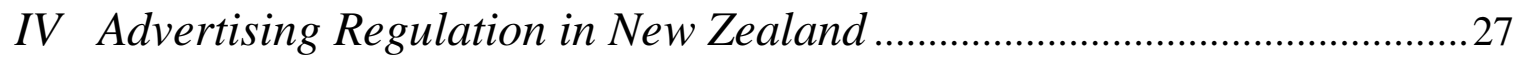

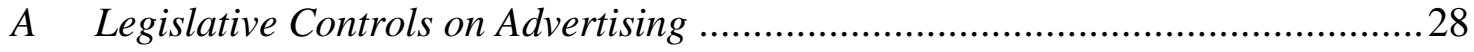

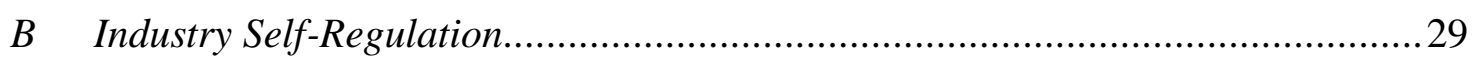

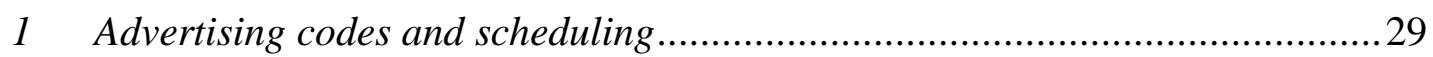

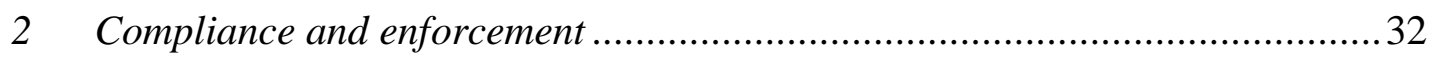

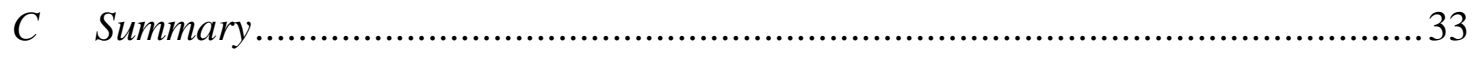

$V \quad$ Comparative Approaches to Advertising Regulation .....................................34

A Advertising Regulation in Europe ……............................................................. 34

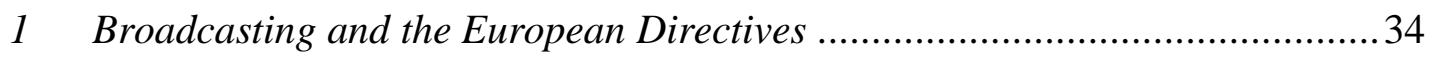

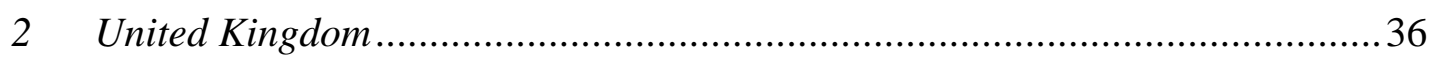

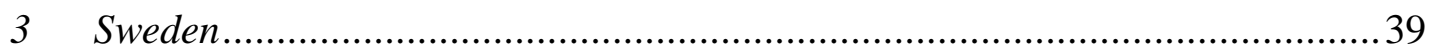

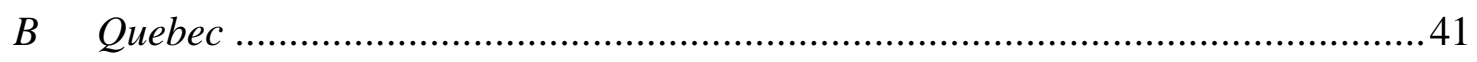


VI The Constitutionality of an Advertising Ban for New Zealand

A A Possible Advertising Ban for New Zealand .....................................................4

B Is an Advertising Ban a Demonstrably Justified Limit upon Freedom of Expression? 46

$1 \quad$ Prescribed by law?

2 Does the limiting measure serve a purpose sufficiently important to justify curtailment of the right or freedom?

3 Is the limiting measure rationally connected to its purpose?

4 Does the limiting measure impair the right or freedom no more than is reasonably necessary for the achievement of its purpose?

5 Is the limit in due proportion to the importance of the objective?

6 Summarising the case for justification

VII Conclusion. 


\begin{abstract}
Obesity is increasingly recognised by policymakers as a threat to public health and wellbeing. Despite obesity's many causes, one commonly cited concern of public health advocates is the prevalence of food and beverage advertising. In particular, concerns have focused upon the targeting of unhealthy food and beverage advertising towards children. The current evidence reveals children's vulnerability to product advertising and its consequential effects upon children's food-related attitudes and behaviours. Though the evidence of a link between food advertising and obesity is equivocal, it is sufficient to make the case for a ban on the advertising of unhealthy food and beverages to children. However, any advertising restrictions upon commercial advertising must be consistent with the right to free expression under the New Zealand Bill of Rights Act 1990. An analysis of the theoretical justifications underlying free speech protections suggests greater leeway should be afforded legislators to regulate in the face of a public health crisis. In spite of the New Zealand Government's willingness to rely upon a self-regulatory framework for advertising regulation, the success of statutory advertising restrictions internationally illustrates the potential for a stronger approach. Though a lack of evidence precludes an objective assessment of the efficacy of the current self-regulatory scheme, the theoretical incompatibility of self-regulation with the achievement of public health goals underscores the need for government-led regulation. Ultimately, the growing threat posed by the obesity epidemic, the absence of reasonable alternatives to statutory restrictions and the narrow scope of a ban on the advertising of unhealthy food and beverages to children mean the suggested ban represents a demonstrably justified limit upon free expression.
\end{abstract}

\title{
Word Length
}

The text of this paper (excluding abstract, table of contents, footnotes and bibliography) comprises approximately 14,997 words.

\section{Subjects and Topics}

Freedom of expression, Bill of Rights, Advertising regulation, Irwin Toy Ltd v Quebec (Attorney General), or Obesity. 


\section{Introduction}

Obesity is a public health issue of growing concern for policymakers throughout the global regulatory environment. The increasingly wide-felt effects of the obesity epidemic upon society have intensified calls for government-led intervention. Public concern has focused particularly upon the prevalence of obesity among children. The continuation of obesity into adulthood, and its implications for individual health and wellbeing, has led children to be identified as an important target for anti-obesity measures.

Despite the many causes of obesity, the promotion of unhealthy foods and beverages is consistently cited as contributing to the obesity epidemic. The New Zealand Government has historically devolved the regulation of advertising to the advertising industry itself. Public health discourse at all levels has repeatedly raised concerns over the predominance of such self-regulatory regimes. The stated requirement for more proactive measures targeting the obesity epidemic has led to calls for stronger government-led regulation of food promotions. Before a more comprehensive framework for advertising regulation can be devised, however, it is necessary to consider the effects of regulation upon the right to free expression under s 14 of the New Zealand Bill of Rights Act 1990. This paper therefore considers whether a government-imposed ban upon the advertising of unhealthy foods to children could be implemented in accordance with New Zealand's existing free speech protections.

Part II of the paper outlines the extent of the obesity epidemic and highlights the alleged connection between food promotion and obesity. In doing so, it reveals children's vulnerability to advertising and its resultant effects upon children's obesity and obesityrelated behaviours. Despite the absence of evidence directly linking food promotions to obesity, the evidence base remains sufficient to present a robust case for more comprehensive advertising restrictions.

Part III then assesses the constitutional argument against further regulation by evaluating advertisers' alleged right of commercial expression. An exploration of the arguments raised 
in support of the protection of commercial expression helps illuminate the constitutional foundation upon which existing advertising regulation rests. The influence of these considerations upon free speech jurisprudence is evident from the treatment of commercial expression within the United States, New Zealand and Canada. These approaches reveal that the limited theoretical justifications underlying the protection of commercial expression have resulted in a lower level of constitutional protection. Such reduced protection therefore provides greater scope for regulatory intervention in circumstances conducive to the public interest.

Having identified the threat posed by the emerging obesity epidemic, Part IV outlines the existing system of advertising regulation within New Zealand. This discussion reveals policymakers' current resort to self-regulatory measures in order to curb the threat posed by obesity. The deficiencies within this self-regulatory framework reinforce the need to consider government-led regulation of food and beverage advertising. Part V builds upon this by presenting a comparative analysis of advertising regulations within the United Kingdom, Sweden and Quebec. In addition to demonstrating the potential for regulatory reform, these differing approaches underscore the fact that stricter regulation is predominantly a function of legislative willingness. The lessons offered by these approaches are therefore useful in informing a possible ban on the advertising of unhealthy food to children in New Zealand.

Finally, Part VI assesses the constitutionality of an advertising ban in light of New Zealand's existing free speech protections. Drawing upon the existing evidence, the paper considers whether a ban upon the advertising of unhealthy foods to children represents a demonstrably justified limit upon advertisers' expression under s 5 of the New Zealand Bill of Rights Act. Here, the existing evidential uncertainty suggests the proposed ban would represent an unjustified limit upon free expression under the Act. Notwithstanding this, a compelling argument exists in favour of stronger government regulation. The evidence of children's vulnerability to persuasive food promotions and the costs imposed by obesity suggest a more lenient approach should be taken to legislative intervention. The need for effective government regulation thus requires that the constitutional protection provided 
by the New Zealand Bill of Rights Act should not be used to cripple the proactive development of social health policy.

\section{The Nature of the Problem}

\section{A The Obesity Epidemic}

\section{Childhood obesity - a global health challenge}

Obesity and overweight involves "abnormal or excessive fat accumulation that may impair health." At a base level, this fat accumulation stems from a sustained period of surplus energy intake. ${ }^{2}$ Governments' concern with obesity stems from its short- and long-term consequences for both individuals and society generally. Children are an important focus of obesity concerns given childhood obesity is a predictor of continued obesity into adulthood. ${ }^{3}$ Children displaying unhealthy eating habits are considered as "laying down their food preferences and dietary habits which will continue into adult life." ${ }^{4}$ In the longterm, obesity is considered causally responsible for the increased prevalence of noncommunicable diseases, such as diabetes and cardiovascular disease. ${ }^{5}$

Public health fears over the obesity epidemic are exacerbated by the growing prevalence of obesity. As of 2010, 43 million preschool children were estimated to be obese globally. ${ }^{6}$ Worryingly, these numbers are increasing, with the global prevalence of childhood

\footnotetext{
${ }^{1}$ World Health Organisation "Obesity and Overweight" (March 2013) <www.who.int/mediacentre/>.

${ }^{2}$ Shin-Yi Chou, Inas Rashad and Michael Grossman "Fast-Food Restaurant Advertising on Television and its Influence on Childhood Obesity" (2008) 51(4) JLE 599 at 600.

${ }^{3}$ See WR Clarke and RM Lauer "Does Childhood Obesity Track Into Adulthood" (1993) 33(5) Critical Reviews in Food Science and Nutrition 423; and Greg Critser Fat Land: How Americans Became the Fattest People in the World (Penguin Books, New York, 2003) at 74-75.

${ }^{4}$ See Kath Dalmeny "Food marketing: the role of advertising in child health" (2003) 13(1) Consumer Policy Review 2 at 2.

${ }^{5}$ World Health Organisation Population-Based Prevention Strategies for Childhood Obesity: Report of the WHO Forum and Technical Meeting (December 2009) at 8; and Delvina Gorton Advertising Food to Children: Background Paper (Heart Foundation New Zealand, April 2011) at 1.

${ }^{6}$ Mercedes de Onis, Monika Blossner and Elaine Borghi "Global prevalence and trends of overweight and obesity among preschool children” (2010) 92(5) American Journal of Clinical Nutrition 1257 at 1259.
} 
overweight and obesity rising from 4.2 per cent in 1990 to 6.7 per cent in $2010 .^{7}$ The continued growth in childhood obesity rates and its associated implications for public health have led to calls for stronger government policies targeting the epidemic.

Obesity's position as a global health challenge is evidenced by the emphasis placed upon it within the global regulatory environment. The World Health Organisation (WHO) has consistently recognised obesity as a public health issue. ${ }^{8}$ In its 2010 report on the prevention of non-communicable diseases, the WHO stated its objective to reduce the modifiable risk factors contributing to non-communicable disease, including factors such as excess weight. ${ }^{9}$ Further discourse at both international and regional levels reinforces the need for better management of obesity and its causes. ${ }^{10}$

\section{Obesity in New Zealand}

Whilst the growth of obesity is predominantly evident within developing nations, ${ }^{11}$ it is not a problem from which New Zealand is insulated. A recent report by the New Zealand Medical Association identified New Zealand's obesity rates as fourth worst in the OECD. ${ }^{12}$ As of 2013, 31 per cent of New Zealand's adult population were obese. ${ }^{13}$ Though obesity rates are lower amongst children, the prevalence of childhood obesity is growing rapidly. One in nine New Zealand children are now obese, with a further 22 per cent of children

\footnotetext{
${ }^{7}$ de Onis, Blossner and Borghi, above n 6, at 1259.

${ }^{8}$ See Boyd Swinburn and others "The 'Sydney Principles' for reducing the commercial promotion of foods and beverages to children" (2008) 11(9) Public Health Nutrition 881 at 881.

${ }^{9}$ World Health Organisation Report by the Secretariat on the Prevention and Control of Noncommunicable Diseases: Implementation of the Global Strategy (A63/12, April 2010) at 3.

${ }^{10}$ See generally Anne Matthews and others The Marketing of Unhealthy Food to Children in Europe: A Report of Phase 1 of the 'Children, Obesity and Associated Avoidable Chronic Diseases' Project (European Health Network, 2005); and Corinna Hawkes "Regulating Food Marketing to Young People Worldwide: Trends and Policy Drivers" (2007) 97(11) American Journal of Public Health 1962.

${ }^{11}$ See generally de Onis, Blossner and Borghi, above n 6.

${ }^{12}$ New Zealand Medical Association Policy Briefing: Tackling Obesity (May 2014) at 4. See also Food and Agriculture Organisation of the United Nations The State of Food and Agriculture (June 2013) at 78.

${ }^{13}$ New Zealand Medical Association, above n 12, at 8.
} 
considered overweight; an increase of 3 per cent since $2007 .{ }^{14}$ Obesity rates are also consistently higher among poorer socioeconomic groups. ${ }^{15}$ This illustrates that the health consequences of obesity often impact those least resourced to deal with them.

In addition to its effects upon individual health and quality of life, obesity imposes significant economic costs upon society. These externalities arise through both the direct health costs borne by the healthcare system and the indirect costs imposed upon society through lost productivity. ${ }^{16}$ In 2006, the healthcare burden attributable to excess weight and obesity was estimated at $\$ 686$ million, 4.5 per cent of New Zealand's total healthcare expenditure. ${ }^{17}$ The individual and collective costs borne by society demonstrate the influence of the obesity epidemic within New Zealand. Given its broad ramifications, the onus is now upon policymakers to devise more comprehensive means of tackling obesity and its causes.

\section{B The Advertising Connection - a Focus upon Children}

Even with obesity's innumerable causes, ${ }^{18}$ the promotion of unhealthy foods remains an important component of the obesity problem. In 2010 the WHO released a set of recommendations seeking to improve states' regulation of food and beverage promotions. ${ }^{19}$ The implementation of children's marketing codes by self-regulatory groups, such as the International Chamber of Commerce, further acknowledges the possible impact of food promotions upon childhood obesity. ${ }^{20}$ The regulation of food and beverage advertising therefore merits discussion when considering potential avenues for public health

\footnotetext{
${ }^{14}$ Ministry of Health New Zealand Health Survey: Annual Update of Key Findings 2012/13 (December 2013) at 43 .

15 New Zealand Medical Association, above n 12, at 8; and Ministry of Health, above n 14, at 43.

${ }^{16}$ New Zealand Medical Association, above n 12, at 7.

${ }^{17}$ New Zealand Medical Association, above n 12, at 7.

18 See Garry Egger and Boyd Swinburn "An 'Ecological' Approach to the Obesity Pandemic" (1997) 315(7106) British Medical Journal 477 at 479; and Gerard Hastings and others Review of Research on the Effects of Food Promotion to Children: Final Report (World Health Organisation, September 2003 ) at 171.

${ }^{19}$ World Health Organisation, above n 9, at 9-15.

${ }^{20}$ See generally Hawkes, above n 10, at 1968.
} 
intervention. In order to achieve this, it is important to understand the effects of advertising and its relationship to obesity.

\section{The vulnerability of children}

Children's susceptibility to advertising represents a significant concern for public health advocates. In comparison with adults, children lack the necessary mental faculties to identify marketing tactics and scrutinise information. ${ }^{21}$ This knowledge gap is explained by the absence of media literacy among young children. ${ }^{22}$ Piaget's three stages of literacy provide an understanding of the differing levels of media literacy among young consumers. ${ }^{23}$ Until the age of eight, children are incapable of understanding the persuasive intent of advertising. ${ }^{24}$ Furthermore, it is not until the age of 12 that children can articulate an understanding of what advertising is trying to achieve. ${ }^{25}$ This developmental gap also explains the differing effects of marketing techniques upon children of varying ages. Younger children are more likely to be persuaded by peripheral marketing stimuli, such as colours and sounds. ${ }^{26}$ Conversely, older children capable of better interpreting messages tend to be persuaded by an advertisement's substantive content. ${ }^{27}$ These considerations demonstrate children's vulnerability to promotions designed to stimulate demand for

\footnotetext{
${ }^{21}$ Helen Dixon and others "Can counter-advertising reduce pre-adolescent children's susceptibility to frontof-package promotions on unhealthy foods? Experimental Research" (2014) 116 Social Science \& Medicine 211 at 212; and M Neil Browne, Lauren Frances Biksacky and Alex Frondorf "Advertising to Children and the Commercial Speech Doctrine: Political and Constitutional Limits" (2009) 58 Drake L Rev 67 at 70-71.

${ }^{22}$ Dalmeny, above n 4, at 4; and Patti M Valkenburg "Media and Youth Consumerism" (2000) 27 Journal of Adolescent Health 52 at 52-53.

${ }^{23}$ See Sonia Livingstone and Ellen J Helsper "Does Advertising Literacy Mediate the Effects of Advertising on Children? A Critical Examination of Two Linked Research Literatures in Relation to Obesity and Food Choice" (2006) 56(3) Journal of Communication 560 at 562.

${ }^{24}$ See Livingstone and Helsper, above n 23, at 562.

${ }^{25}$ See Livingstone and Helsper, above n 23, at 562. Contrast Lynne Eagle and Anne de Bruin "Advertising Restrictions: Protection of the Young and Vulnerable?" (2001) 2(4) Young Consumers 259 at 263, who suggest modern children are considerably more media literate than earlier generations.

${ }^{26}$ See Livingstone and Helsper, above n 23, at 572.

${ }^{27}$ See Livingstone and Helsper, above n 23 at 572.
} 
unhealthy foods. As consumers, children are incapable of interpreting and acting upon such messages in a rational manner. ${ }^{28}$

Collective concerns regarding children's advertising are intensified by the increasingly targeted nature of food promotions. The advertising industry's emphasis upon young consumers stems from their significant current and future market potential. ${ }^{29}$ This potential is evident from figures placing the total purchase influence of children globally at USD 1.88 trillion. $^{30}$ The growing influence of young consumers has had significant consequences for the advertising industry. ${ }^{31}$ The importance of new market development has seen children's marketing become a "core part of overall marketing strategy." 32 This development has also led to marked changes in the nature of promotions themselves. The use of marketing techniques appealing to more hedonistic values, such as humour and taste, has become characteristic of an industry oriented towards youth consumerism. ${ }^{33}$ As a result, it is not only children's vulnerability to advertising that represents a threat, but the proclivity of marketers to exploit such vulnerability through their promotions.

The augmented nature of food promotions is further reinforced by the volume and diversity of modern advertising. In 2005, the total advertising expenditure for fast food chains and restaurants in New Zealand was $\$ 67$ million. ${ }^{34}$ A further $\$ 57$ million was spent on the advertising of chocolate, confectionary and aerated drinks. ${ }^{35}$ This expenditure results in significant levels of advertising exposure for products high in fat, sugar and salt. A 2005 study found that New Zealand children watching two hours of free-to-air television per day

\footnotetext{
${ }^{28}$ See Gorton, above $\mathrm{n} 5$, at 1.

${ }^{29}$ See Browne, Biksacky and Frondorf, above n 21, at 69.

${ }^{30}$ Martin Lindstrom BRANDchild (Kogan Page, London, 2003) at 193.

${ }^{31}$ See Livingstone and Helsper, above n 23, at 561; and Critser, above n 3, at 114.

${ }^{32}$ See Parke Wilde "Self-regulation and the response to concerns about food and beverage marketing to children in the United States" (2009) 67(3) Nutrition Reviews 155 at 160.

${ }^{33}$ See generally Georgina Cairns, Kathryn Angus and Gerard Hastings The Extent, Nature and Effects of Food Promotion to Children: A Review of the Evidence to December 2008 (World Health Organisation, December 2009) at 16.

${ }^{34}$ Gorton, above $\mathrm{n} 5$, at 2 .

${ }^{35}$ Gorton, above n 5, at 2.
} 
would see a total of 7,134 advertisements per year. ${ }^{36}$ Over the course of an average childhood, this level of exposure amounts to seeing 92,000 food advertisements. ${ }^{37}$ Children's exposure is further compounded by the increased fragmentation of marketing communications. ${ }^{38}$ With greater recourse to media such as sponsorship and the internet, marketers' integrated use of promotional media has resulted in a more pervasive marketing environment. ${ }^{39}$ The pervasiveness of modern marketing has thereby exacerbated the difficulties faced in protecting children from potentially harmful marketing messages.

\section{Food advertising and its effects on children}

Children's vulnerability to advertising allows marketers to substantially influence children and their relationship with food. One of the primary effects of food promotions is to modify children's food-related attitudes and beliefs. Research demonstrates that food advertisements have statistically significant effects upon both product preference and purchase. ${ }^{40}$ These effects are amplified by advertising's effect upon brand recall, with children three times more likely to recall an advertised product than adults. ${ }^{41}$ Advertising's influence upon young consumers is often manifested through 'pester power', children's requests to parents for particular products. ${ }^{42}$ Quantitative research shows that such requests are an important determinant of parents' food choices. ${ }^{43}$ Given food promotions' potential to normalise unhealthy eating behaviours, ${ }^{44}$ the attitudinal effects of advertising pose significant concerns for children's health.

\footnotetext{
${ }^{36}$ Nick Wilson and others "Marketing fat and sugar to children on New Zealand television" (2006) 42 Preventive Medicine 96 at 97.

${ }^{37}$ Wilson and others, above $\mathrm{n} 36$, at 99.

${ }^{38}$ See Hawkes, above n 10, at 1962; and Lindstrom, above n 30, at 194.

${ }^{39}$ See Livingstone and Helsper, above n 23, at 561.

${ }^{40}$ See Hastings and others, above n 18, at 130 and 137; and Cairns, Angus and Hastings, above n 33, at 28 and 30 .

${ }^{41}$ Lindstrom, above n 30, at 64. See Cairns, Angus and Hastings, above n 33, at 24.

${ }^{42}$ See Brian M Young, Anne de Bruin and Lynne Eagle "Attitudes of Parents Toward Advertising to Children in the UK, Sweden and New Zealand" (2003) 19 Journal of Marketing Management 475 at 484; and Cairns, Angus and Hastings, above n 33, at 25.

${ }^{43}$ See United Kingdom Office of Communications Childhood Obesity - Food Advertising in Context (July 2004) at 58.

${ }^{44}$ See United Kingdom Office of Communications, above n 43, at 111.
} 
In addition to its attitudinal effects, food promotions also have a moderate effect upon children's consumption behaviours. Research indicates that the portrayal of food consumption cues, such as images of models eating, creates 'primes' that stimulate corresponding eating behaviours among viewers. ${ }^{45}$ Further research suggests that these primes stimulate consumption of both the advertised brand and energy-dense products generally. ${ }^{46}$ Despite conflicting studies, there remains sufficient evidence that advertising exerts a modest direct effect upon children's food consumption. ${ }^{47}$

\section{The obesity connection}

Though research has identified a direct link between advertising and the food-related attitudes and behaviours of children, evidence of a direct link to obesity itself remains limited. Several studies have attempted to measure advertising's effect upon obesity by controlling for other moderating factors. One study has suggested a complete ban on television advertising would reduce the number of overweight children aged 3-11 by 18 per cent. ${ }^{48}$ Other studies, whilst establishing some connection between advertising and obesity, suggest advertising explains a minimal degree of the variance in children's obesity rates. ${ }^{49}$ The evidence base establishing a connection between food promotion and obesity is therefore considered circumstantial. ${ }^{50}$

The difficulties in establishing an evidential connection between food promotion and obesity result from obesity's multiple causes and the difficulty in controlling for these

\footnotetext{
45 Jennifer L Harris, John A Bargh and Kelly D Brownell "Priming Effects of Television Food Advertising on Eating Behaviour" (2009) 28(4) Health Psychology 404 at 405-407.

${ }^{46}$ Moniek Buijzen, Joris Schuurman and Elise Bomhof "Associations between children's television advertising exposure and their food consumption patterns: A household diary-survey study" (2008) 50 Appetite 231 at 237.

${ }^{47}$ See Hastings and others, above n 18, at 148; and Cairns, Angus and Hastings, above n 33, at 31.

${ }^{48}$ See Chou, Rashad and Grossman, above n 2, at 616.

${ }^{49}$ See RN Bolton "Modelling the impact of television food advertising on children's diets" in JH Leigh and CR Martin (eds) Current Issues and Research in Advertising (University of Michigan, Ann Arbor (MI), 1983) 173, as cited in Hastings and others, above n 18, at 150.

${ }^{50}$ See Janny M Goris and others "Television Food Advertising and the Prevalence of Childhood Overweight and Obesity: a Multicountry Comparison” (2009) 13(7) Public Health Nutrition 1003 at 1003.
} 
causes within experimental research. Research targeting links between food promotion and obesity is often complicated by the physical inactivity and food consumption associated with advertising exposure. ${ }^{51}$ These factors create uncertainties when attempting to identify any exposure-response relationship. ${ }^{52}$ In addition, the conclusions drawn from research are generally based upon correlational data incapable of describing the size and nature of advertising's influence upon obesity. ${ }^{53}$

The inadequacies of experimental research techniques are compounded by the fact that food promotion's effects are moderated by a variety of environmental factors. Hastings surmises the current evidential difficulties facing advocates for stricter advertising regulation as follows: ${ }^{54}$

The relatively small number of studies and the heterogeneous range of other dietary influence factors, means that it is not possible to draw definitive conclusions about the size of food promotion's influence on children relative to attitudinal, behavioural, familial, socio-economic and other factors.

Current research therefore lacks an understanding of the extent to which food and beverage promotion impacts the prevalence of obesity without the influence of these additional environmental factors. These evidential deficiencies form the primary basis for arguments that further advertising regulation will not suppress rising obesity concerns. ${ }^{55}$

Despite this gap in the evidence linking advertising to obesity, the argument for stricter regulation of children's food promotions remains strong. Logic suggests that the sheer

51 T Lobstein and S Dibb "Evidence of a possible link between obesogenic food advertising and child overweight" (2005) 6 Obesity Reviews 203 at 204.

52 Goris and others, above n 50, at 1010 .

53 See Buijzen, Schuurman and Bomhof, above n 46, at 237; and Pimbucha Rumevichientong and others "The Impact of Food Advertisements on Changing Eating Behaviours: An Experimental Study" (2014) 44 Food Policy 59 at 59.

${ }^{54}$ Hastings and others, above n 18, at 171.

55 See David Ashton "Food advertising and childhood obesity" (2004) 97(2) Journal of the Royal Society of Medicine 51 at 51-52. 
volume of food advertising indicates its effect upon children's consumption. ${ }^{56}$ If advertising did not have the effect of increasing demand for the products advertised, industry groups would be indifferent to its regulation. ${ }^{57}$ Furthermore, the evident impact of obesity upon society underscores the need for more tangible means of addressing the obesity epidemic. The existing evidence base demonstrates that advertising exerts some influence upon children's consumption habits. This influence is exacerbated by children's vulnerability to persuasive marketing messages. A precautionary approach to public health intervention would enable legislators to regulate on the basis of such evidential uncertainty. ${ }^{58}$ Obesity's effects upon New Zealand society and the possible evidence of advertising's contribution to the growing epidemic therefore provide a sufficient basis to consider further regulatory intervention.

\section{Freedom of Expression}

\section{A Freedom of Expression and the Concept of Commercial Expression}

\section{Advertising and freedom of expression concerns}

The regulation of advertising is inevitably opposed by commercial interests on the grounds of freedom of expression. In the context of advertising, these concerns speak to the issue of commercial expression and its legitimacy as a constitutionally protected right. That advertising restrictions are already accepted in some contexts illustrates that commercial expression may be subject to regulation. ${ }^{59}$ It is therefore important to understand what commercial expression is, and the justifications underlying its constitutional protection, in order to assess the potential for stronger restrictions upon the advertising of unhealthy foods to children. This Part focuses upon three principal arguments raised in support of commercial expression protections: the idea that commercial expression furthers individual autonomy, the marketplace of ideas concept and the anti-paternalist argument against

\footnotetext{
${ }^{56}$ See Wilde, above n 32, at 161; and Chou, Rashad and Grossman, above n 2, at 602.

57 See Wilde, above n 32, at 161.

${ }^{58}$ See Rob Moodie and others "Profits and pandemics: prevention of harmful effects of tobacco, alcohol, and ultra-processed food and drink industries" (2013) 381(9867) Lancet 670 at 676.

${ }^{59}$ See for example Financial Markets Conduct Act 2013; and Smoke-free Environments Act 1990.
} 
government intervention. It then assesses how these theoretical considerations have affected the relevant jurisprudence within Canada, New Zealand and the United States. This assessment reveals that the limited theoretical justification for commercial expression's constitutional protection may legitimise stronger government regulation of food promotions within New Zealand.

\section{What is commercial expression?}

Definitional issues have consistently plagued the commercial expression debate since its beginning. ${ }^{60}$ Some expression, such as advertising, appears paradigmatic of commercial expression. The potential breadth of commercial expression, however, precludes the adoption of any definition that turns on the expression's medium or form. ${ }^{61}$ These difficulties explain courts' reluctance to adopt a precise definition of commercial expression. ${ }^{62}$

A popular approach towards defining commercial expression has been to analyse the motives of the speaker. ${ }^{63}$ Sharpe suggests commercial expression is distinguished by messages that propose or entice a specific decision on behalf of the recipient. ${ }^{64}$ This motives-based approach is commonly reflected within judicial conceptions of commercial expression. In Virginia State Board of Pharmacy v Virginia Citizens Consumer Council, the United States Supreme Court defined 'pure' commercial expression as expression that communicates the idea that "I will sell you the X [product] at the Y price." ${ }^{\circ 5}$ Adopting a broader definition, Pittsburgh Press Co v Pittsburgh Commission on Human Relations held

\footnotetext{
${ }^{60}$ See Colin R Munro "The Value of Commercial Speech" (2003) 62(1) CLJ 134 at 149.

${ }^{61}$ See Munro, above n 60, at 150-153. See Nike Inc v Kasky 539 US 654123 (2003) and Markt Intern \& Beerman v Germany (1990) 12 EHRR 161 as examples of the potential breadth of commercial expression.

${ }^{62}$ See S Shiffrin "The First Amendment and Economic Regulation: Away from a General Theory of the First Amendment" (1983) 78 NWULR 1212 at 1213; and Roger A Shiner Freedom of Commercial Expression (Oxford University Press, Oxford, 2003) at 6.

${ }^{63}$ See TM Scanlon "Freedom of Expression and Categories of Expression" (1979) 40 U Pitt L Rev 519 at 540.

${ }^{64}$ Robert J Sharpe "Commercial Expression and the Charter" (1987) 37(3) UTLJ 229 at 230.

${ }^{65}$ Virginia State Board of Pharmacy v Virginia Citizens Consumer Council Inc 425 US 748 (1976) at 761 per Blackmun J.
} 
that commercial expression does "no more than propose a commercial transaction." 66 Such approaches place substantial emphasis upon the economic interests of the speaker and their relevant audience. ${ }^{67}$

Despite the attractiveness of a motives-based approach, inherent difficulties in its application remain. Munro suggests the difficulty in distinguishing intent in cases of commercial expression means this approach risks blurring the distinction between other categories of protected speech. ${ }^{68}$ In particular, artists often exercise their right of artistic expression for the purpose of realising a profit. A motives-based approach to categorising expression therefore risks chilling artistic expression of this nature. These difficulties illustrate that, whilst reference to an economic purpose serves as a useful "touchstone" for 'pure' commercial expression, its ill-defined scope precludes a cohesive definition. ${ }^{69}$

The difficulty in formulating a broadly applicable definition of commercial expression raises questions over the logic of classifying it as a separate category of expression. The inability to distinguish between artistic and commercial expression potentially undermines the categorisation of certain commercial activities, such as advertising. The apparent inconsistency of a categorical approach with modern 'lifestyle' advertising that does not propose a specific transaction presents difficulties when attempting to define expression. ${ }^{70}$ With substantial investment often involved in producing advertisements, advertising content may ultimately merit protection on the grounds of artistic merit, regardless of its apparent commercial bent. The task of extricating the separate commercial and noncommercial elements of expression illustrates the difficulties posed by a categorical

\footnotetext{
${ }^{66}$ Pittsburgh Press Co v Pittsburgh Commission on Human Relations 413 US 376 (1973) at 385.

${ }^{67}$ See Eric Barendt Freedom of Speech ( $2^{\text {nd }}$ ed, Oxford University Press, Oxford, 2009) at 396; and Central Hudson Gas \& Electric Corp v Public Service Commission of New York 447 US 557 (1980) at 561.

${ }^{68}$ Munro, above n 60, at 154. See also Keith Dubick “Commercial Expression: A 'Second-Class' Freedom?" (1996) 60 Sask L Rev 91 at 96.

${ }^{69}$ See Dubick, above n 68, at 93.

${ }^{70}$ See Alex Kozinski and Stuart Banner "Who's Afraid of Commercial Speech?” (1990) 76(4) Va L Rev 627 at 639; and Shiner, above n 62, at 7.
} 
approach. Some commentators have suggested this necessitates that commercial expression be protected in a manner commensurate with other forms of speech. ${ }^{71}$

Notwithstanding this uncertainty, advertising is commonly accepted as an example of pure commercial expression. ${ }^{72}$ Contemporary free speech jurisprudence illustrates courts' predilection for a more inclusive definition of expression that includes commercial expression to the extent that it is accepted as such. ${ }^{73}$ Commercial expression is thus well established as a form of protected expression. It is therefore important to identify the precise level of protection afforded this expression in order to evaluate the constitutionality of more restrictive advertising regulations.

\section{B The Argument for the Constitutional Protection of Commercial Expression}

\section{Autonomy-based arguments}

Freedom of expression is widely recognised as enabling personal autonomy and selffulfilment. ${ }^{74}$ The consideration of personal autonomy in the context of commercial expression, however, is prone to debate. Many critics contend that the autonomous values which merit protection are not engaged in a commercial context. ${ }^{75}$ Shiner conceives of personal autonomy as a value for "natural persons."76 This view of autonomy appears consistent with the theoretical conception of free expression traditionally presented within liberal speech theory. Despite this view, modern legal systems have increasingly evolved to attribute anthropomorphic concepts to corporations. The concept of independent legal personality supports the argument that autonomy values should be attributed to corporate

\footnotetext{
${ }^{71}$ See Kozinski and Banner, above n 70, at 648.

${ }^{72}$ See generally Irwin Toy v Quebec (Attorney General) [1989] 1 SCR 927.

${ }^{73}$ See Shiner, above $\mathrm{n} 62$, at 8 .

${ }^{74}$ See Thomas I Emerson The System of Freedom of Expression (Random House, New York, 1970) at 6; and Shiner, above n 62, at 166.

${ }^{75}$ See Shiner, above n 62, at 168-169; and Sharpe, above n 64, at 236. For a judicial discussion of this criticism see also RJR-MacDonald Inc v Canada (Attorney General) [1995] 3 SCR 199 at [72] per La Forest J dissenting.

${ }^{76}$ Shiner, above n 62, at 189.
} 
entities. ${ }^{77}$ Notwithstanding this fact, other commentators have suggested that corporations' economic motives preclude their characterisation as autonomous beings. ${ }^{78}$ Although the case for corporate autonomy is arguable, the prevailing belief remains that commercial expression does not significantly advance the autonomy of the expresser. ${ }^{79}$ It is therefore necessary to identify some other basis for the autonomy argument.

Autonomy-based arguments for commercial speech protection derive strong support from receivers' reciprocal interest in information. Freedom of expression is universally recognised as encapsulating the rights of receivers. ${ }^{80}$ In upholding the constitutional protection of commercial expression, the Supreme Court of Canada in Ford v Quebec (Attorney General) emphasised commercial expression's role in enabling informed decision-making, an important aspect of personal autonomy. ${ }^{81}$ Sharpe suggests that, as consumers' choices are a manifestation of autonomy, commercial expression that informs these choices may merit protection. ${ }^{82}$ In this sense, commercial expression is said to enhance autonomy both on an instrumental basis and through its intrinsic value in allowing consumers to control their own destiny. ${ }^{83}$

Despite receivers' interest in commercial expression, it is unclear whether the information conveyed bears any relation to personal autonomy. Shiner advocates that not all choices can be said to reflect autonomy, ${ }^{84}$ citing a disconnect between informed economic choice and the concept of individual self-realisation. ${ }^{85}$ Despite widespread judicial recognition of

\footnotetext{
${ }^{77}$ See Companies Act 1993, s 15. In some jurisdictions, the concept of corporate autonomy is reflected in the offence of corporate manslaughter, see for example Corporate Manslaughter and Corporate Homicide Act 2007 (UK).

${ }^{78}$ See C Edwin Baker "Commercial Speech: A Problem in the Theory of Freedom" (1976) 62 Iowa L Rev 1 at 13; and Ian Cram Contested Words: Legal Restrictions on Freedom of Speech in Liberal Democracies (Ashgate, Aldershot (UK), 2006) at 175.

${ }^{79}$ See Shiner, above n 62, at 168-169.

${ }^{80}$ See Sharpe, above n 64, at 223; and Virginia Board, above n 65, at 762-763 per Blackmun J.

${ }^{81}$ Ford $v$ Quebec (Attorney General) [1988] 2 SCR 712 at 760.

${ }^{82}$ Sharpe, above $\mathrm{n}$ 64, at 237 and 259.

${ }^{83}$ See Martin H Redish “The Value of Free Speech" (1982) 130(3) U Pa L Rev 591 at 620-621.

${ }^{84}$ Shiner, above $\mathrm{n} 62$, at 230.

${ }^{85}$ Shiner, above n 62 at 236.
} 
the importance of economic choice, ${ }^{86}$ commentators question whether economic selfrealisation can be equated with self-realisation that pertains to liberty and personal discovery. ${ }^{87}$ When expression is viewed as "an integral part of the development of ideas, of mental exploration and of the affirmation of self," 88 the economic motives behind commercial expression appear inconsistent with the autonomy values underlying free speech protections. ${ }^{89}$

Children's impaired ability to interpret advertising also calls into question the argument that advertising restrictions inhibit their autonomy as receivers. The evidence establishing children's diminished media literacy, ${ }^{90}$ coupled with research identifying advertising's role as a subliminal consumption cue, ${ }^{91}$ suggests children may not be truly autonomous when acting upon the information presented within food promotions. Advertisers therefore manipulate the role of children as receivers in order to preserve their continued interest in advertising. Those benefitting from children's purported right to receive information are not receivers themselves, but expressers. In such circumstances, an argument for the constitutional protection of commercial expression on the grounds of receivers' rights to receive information is wholly unfounded.

Autonomy-based arguments provide some basis for constitutional protection. ${ }^{92}$ However, the inconsistency of commercial expression with traditional autonomy values raises concerns over the appropriate scope of protection afforded. The answer therefore appears to lie in a compromise that recognises the possible value of commercial expression to

\footnotetext{
${ }^{86}$ See for example Virginia Board, above n 65, at 763; and RJR-MacDonald, above n 75, at 343.

${ }^{87}$ See Cram, above n 78, at 176.

${ }^{88}$ See Thomas I Emerson "Toward a General Theory of the First Amendment" (1963) 72 YLJ 877 at 879.

${ }^{89}$ See Baker, above n 78, at 13.

${ }^{90}$ See Dalmeny, above n 4, at 4; Valkenburg, above n 22, at 52; and Livingstone and Helsper, above n 23, at 560 .

${ }^{91}$ See Harris, Bargh and Brownell, above n 45, at 405-407.

${ }^{92}$ See Sharpe, above n 64, at 237.
} 
receivers, ${ }^{93}$ whilst acknowledging that such expression does not enjoy protections commensurate with other forms of expression.

\section{The 'marketplace of ideas'}

The 'marketplace of ideas' concept reflects society's alleged interest in the free flow of commercial information. The concept's genesis lies in the statement of Holmes J in Abrams $v$ United States that " $[\mathrm{t}]$ he best test of truth is the power of the thought to get itself accepted in the competition of the market."94 This argument rests upon the notion that freedom of expression protects an open exchange of views that facilitates the search for truth. ${ }^{95}$ Where citizens are able to obtain information relating to decisions that affect their own welfare, it is not for government to regulate that information's dissemination. ${ }^{96}$

The marketplace concept supports the argument that the best means of ameliorating the effects of harmful expression is through facilitating more speech. ${ }^{97}$ Unlike speech restrictions, this 'counterspeech' exposes existing mistruths through the process of discussion and education. ${ }^{98}$ Commercial expression is therefore said to merit protection on the grounds that its dissemination is conducive to revealing the truth. ${ }^{99}$ This argument finds strong support in economic theory. In particular, a competitive market approach suggests that the greater value placed upon truthful expression will result in that information 'outcompeting' misleading and harmful expression. ${ }^{100}$ Issues persist, however, over the extent to which a marketplace of ideas accurately reflects economic theory.

\footnotetext{
93 See Karla K Gower “Looking Northward: Canada’s Approach to Commercial Expression” (2005) 10 Comm L \& Pol'y 29 at 58.

${ }^{94}$ Abrams $v$ United States 250 US 616 (1919) at 630 per Holmes J dissenting.

95 See Sharpe, above n 64, at 232.

96 See Shiner, above n 62, at 273 and 275. See also United States v Edge Broadcasting Company 509 US 418 (1993) at 437-438 per Stevens J dissenting.

97 See Caroline Reid "Freedom of Expression, Commercial Expression and Tobacco in Canada" (2008) 39 VUWLR 343 at 349.

98 Whitney v California 274 US 357 (1927) at 377 per Brandeis J.

99 See Shiner, above n 62, at 300.

100 See RH Coase “Advertising and Free Speech" (1977) 6 JLS 1; and Aaron Director "The Parity of the Economic Market Place” (1964) 7 JLE 1.
} 
Despite its attractiveness, the marketplace concept exhibits a number of limitations. Firstly, the concept overemphasises receivers' capacity to rationally interpret information. ${ }^{101}$ In an environment characterised by a multiplicity of commercial messages, the reality is that consumers' ability to process information is restricted, particularly when presented with incomplete information. ${ }^{102}$ There are simply too many messages for consumers to process rationally. Children's proven inability to scrutinise marketing communications further exemplifies consumers' diminished rationality when faced with significant quantities of advertising for unhealthy foods. ${ }^{103}$

The application of the marketplace concept to food promotions is also inappropriate given the existing disparity between the volume of advertising promoting unhealthy food and that promoting healthier dietary alternatives. The marketplace concept posits that desirable ideas will eventually outcompete and marginalise harmful information. ${ }^{104}$ The current misalignment of advertising expenditure, however, inhibits the salience of anti-obesity messages within the marketplace of ideas. For every dollar spent by the WHO on noncommunicable disease prevention, the food industry spends USD 500 promoting unhealthy foods. ${ }^{105}$ The result is a marketplace in ideas that is not conducive to the equal availability of information, and which inhibits the flow of information necessary to convey a wellrounded image of children's nutrition. Government regulation is therefore necessary to moderate the flow of information encountered by receivers and enable the communication of more healthful messages.

The difference in operation between a marketplace in material goods and a marketplace in ideas is also pertinent. The greater elusiveness of truth in the context of political expression underscores the intolerance towards regulations suppressing expression in the absence of an objective truth. ${ }^{106}$ In the context of commercial expression, the provability of

\footnotetext{
101 See Shiner, above n 62, at 279.

102 See Shiner, above n 62, at 279.

103 See generally Valkenburg, above n 22; and Livingstone and Helsper, above n 23.

104 See Shiner, above n 62, at 300.

105 Gorton, above n 5, at 1.

106 See Sharpe, above n 64, at 235-236.
} 
commercial statements arguably justifies a greater role for government regulation. ${ }^{107}$ Such arguments demonstrate that, whilst the 'marketplace of ideas' rationale justifies the protection of commercial speech, its application also permits much greater regulation than is acceptable for other types of expression. ${ }^{108}$

\section{Paternalism}

The approaches discussed in this paper suggest that the regulation of commercial expression is generally justified to the extent that such expression is untruthful or misleading. ${ }^{109}$ Greater contention emerges, however, when legislatures seek to regulate on the grounds of consumer protection. Whilst such discussion largely assumes that commercial speech would otherwise enjoy constitutional protection, it raises important issues regarding legislators' mandate to regulate on the basis that consumers are incapable of acting in their own best interest.

The primary basis for anti-paternalist criticism is the argument that individuals must be trusted to make legal choices on the basis of the information available to them. ${ }^{110}$ This notion stems from John Stuart Mill's famous statement that: ${ }^{111}$

The only purpose for which power can be rightfully exercised over any member of a civilised community, against his will, is to prevent harm to others. His own good, either physical or moral, is not a sufficient warrant.

Consequently, the paternalistic shielding of citizens from information affecting personal choice stands to restrict individual autonomy. ${ }^{112}$ Furthermore, it is suggested that the

\footnotetext{
${ }^{107}$ See Sharpe, above n 64, at 235-236.

${ }^{108}$ See Sharpe, above $\mathrm{n}$ 64, at 236.

${ }^{109}$ For example see Virginia Board, above n 65, at 771-773 per Blackmun J. See also Redish, above n 83, at 634.

${ }^{110}$ See Redish, above n 83, at 618; and Virginia Board, above n 65, at 771-773.

111 John Stuart Mill "On Liberty" in B Wishy (ed) Prefaces to Liberty: Selected Writings (University Press America, Larsham (MD), 1959) as cited in REG Upshur "Principles for the Justification of Public Health Intervention" (2002) 93(2) Canadian Journal of Public Health 101 at 102. See also Redish, above n 83, at 636.

${ }^{112}$ See Redish, above n 83, at 636.
} 
diminished level of protection afforded commercial speech enables the suppression of unpopular sentiments under the guise of regulation. ${ }^{113}$ Although the risk of a heavy-handed approach to regulation does exist, the suggestion that regulation could be characterised as a manipulation of consumer choice is a strong one. ${ }^{114}$

Whilst these anti-paternalist arguments have merit, such criticisms ignore the distinction between paternalism and consumer protection. Whilst much regulation of commercial advertising has a paternalistic component, it also overwhelmingly reflects an attempt to quell a wider social harm. ${ }^{115}$ Where a legitimate state interest exists in reducing social harm, the collective benefit in regulation inevitably outweighs questions of individual autonomy. ${ }^{116}$ Similar societal concerns are reflected in the current obesity debate. The existing evidence demonstrates obesity's widespread consequences for individual and collective welfare. Given the possible influence of food promotions upon the obesity epidemic, the argument in favour of constraining individual rights in support of a wider public health objective is compelling. The fact that many democratic constitutions permit proportionate and demonstrably justified restrictions upon truthful advertising suggests that anti-paternalist concerns must ultimately give way to the wider social interest. ${ }^{117}$

\section{Comparative Approaches to the Commercial Expression Doctrine}

\section{$1 \quad$ United States}

In spite of the free speech guarantee contained within the First Amendment of the United States Constitution, the extent of constitutional protection afforded commercial speech has varied substantially since its emergence as a distinct category of speech in Valentine $v$ Chrestensen. ${ }^{118}$ Though recognisant of the existence of commercial speech, the initial

\footnotetext{
${ }^{113}$ See Kozinski and Banner, above n 70, at 649-650.

${ }^{114}$ Contrast 44 Liquormart Inc v Rhode Island 517 US 484 (1996) at 526 per Thomas J dissenting.

${ }^{115}$ See Cram, above n 78, at 178.

116 See Cram, above n 78, at 178.

${ }^{117}$ See Cram, above n 78, at 178.

118 Valentine v Chrestensen 316 US 52 (1942).
} 
position of the United States Supreme Court was that the Constitution imposed no restriction upon Congress's ability to regulate purely commercial advertising. ${ }^{119}$

Subsequent jurisprudence reveals a substantial softening of this position. In Virginia Board, the Court determined that speech that did "no more than propose a commercial transaction" was entitled to constitutional protection. ${ }^{120}$ In reaching its conclusion, the Court emphasised the importance of consumers' interest in the free flow of commercial information, an interest that "may be as keen, if not keener by far, than [their] interest in the day's most urgent political debate." 121 Though critical of a paternalistic approach to regulation, ${ }^{122}$ the Court remained open to the possibility of commercial speech restrictions. In particular, the Court was reluctant to extend free speech protection where speech was untruthful or misleading. ${ }^{123}$

Whilst Virginia Board represented a breakthrough for the commercial expression doctrine, it was not until Central Hudson Gas \& Electric Corp v Public Service Commission of New York that the doctrine became 'operationalised'. ${ }^{124}$ In overturning the Commission's advertising regulations, the Court again recognised the value of commercial expression both to the speaker and the audience. ${ }^{125}$ Although critical of the 'highly paternalistic' view that the legislature enjoyed unchecked powers of regulation, ${ }^{126}$ however, the Court recognised the lesser protection afforded commercial speech. ${ }^{127}$ The Court then outlined a test against which the constitutionality of commercial speech regulations could be assessed. The test can be summarised as follows: ${ }^{128}$

\footnotetext{
${ }^{119}$ At 54.

120 Virginia Board, above n 65, at 762; citing Pittsburgh Press Co v Pittsburgh Commission on Human Relations 413 US 376 (1973) at 385.

${ }^{121}$ At 763.

${ }^{122}$ At 765 and 770.

${ }^{123}$ At 771-773.

${ }^{124}$ Central Hudson, above n 67; see Shiner, above n 62, at 53.

125 Central Hudson, above n 67, at 561-562.

${ }^{126}$ At 562.

127 At 563.

${ }^{128}$ At 566.
} 
(1) to be protected, commercial speech must concern lawful activity and not be misleading;

(2) the government interest in regulating speech must be substantial;

(3) the restriction must directly advance the state interest involved; and

(4) the regulation must not be more extensive than necessary to serve that interest.

This approach reaffirmed the idea that commercial speech merits some protection, albeit at a level reflecting its subordinate nature. ${ }^{129}$

Despite Central Hudson's operationalisation of the commercial expression doctrine, the extent of regulators' discretion remained unclear. This uncertainty was reflected in Posadas de Puerto Rico Associates v Tourism Company of Puerto Rico, in which the Supreme Court upheld a total ban on gambling advertising. ${ }^{130}$ In deferring to the legislature on questions of proportionality under the Central Hudson test, ${ }^{131}$ Posadas demonstrates the potential scope enjoyed by regulators to suppress commercial speech. ${ }^{132}$ This leniency can be sharply contrasted with the Court's subsequent decision in 44 Liquormart Inc $v$ Rhode Island. ${ }^{133}$ Despite the majority's acceptance of the Central Hudson test, the Court was critical of the weak interpretation of the test adopted in Posadas. ${ }^{134}$ The Court emphasised that, notwithstanding the reduced protection enjoyed by commercial speech, ${ }^{135}$ the government must make a real case for regulation. ${ }^{136}$ Whilst this approach acknowledges that the legislature remains the apposite decision-maker in areas of social policy, ${ }^{137}$ it imposes much greater scrutiny upon any resultant regulations.

\footnotetext{
${ }^{129}$ See Shiner, above n 62, at 55.

${ }^{130}$ Posadas de Puerto Rico Associates v Tourism Company of Puerto Rico 478 US 328 (1986).

131 Posadas, above n 130, at 344.

132 See Shiner, above n 62, at 57.

13344 Liquormart, above n 114.

134 At 509-510 per Stevens J.

135 At 501 per Stevens J.

136 At 505-506 per Stevens J.

${ }^{137}$ See Cram, above n 78, at 185.
} 
The attitude of the United States Supreme Court towards the constitutional protection of commercial speech is therefore best viewed as an attempt to reconcile a legislative mandate to set economic and social policy with the utility derived from commercial speech. Whilst its jurisprudence admits of some protection for commercial expression, the Court's categorical approach affirms that this protection is at a lower level.

\section{Canada}

Freedom of expression in Canada is protected through a constitutional guarantee contained within s 2(b) of the Canadian Charter of Rights and Freedoms. ${ }^{138}$ Section 1 provides that protected expression remains subject only to such limits "as can be demonstrably justified in a free and democratic society." ${ }^{139} R v$ Oakes established that, provided the regulator's objective is of sufficient importance, limits upon protected rights will be demonstrably justified where: ${ }^{140}$

(1) the measures adopted are designed to achieve the relevant objective;

(2) the limiting measure impairs the right no more than reasonably necessary; and

(3) the effects of the measures upon the relevant Charter right are proportionate to the desired objective.

Despite the Supreme Court's initial reluctance to protect commercial expression, ${ }^{141}$ its adoption of a "large and liberal interpretation" of the Charter in Ford v Quebec (Attorney General) necessitated the extension of free speech protections to commercial expression. ${ }^{142}$ Unlike the position in the United States, however, the Supreme Court has refused to characterise commercial expression as a distinct category of expression. In Ford, the Court explained that the term 'commercial expression' did not convey any particular

\footnotetext{
${ }^{138}$ Canadian Charter of Rights and Freedoms (Part 1 of Constitution Act) 1982 RS C c-11, s 2(b).

${ }^{139}$ Canadian Charter of Rights and Freedoms, s 1.

${ }^{140} R$ v Oakes [1986] 1 SCR 103 at [74].

${ }^{141}$ See Re Klein and Law Society of Upper Canada (1985) 16 DLR $\left(4^{\text {th }}\right) 489$.

${ }^{142}$ Ford, above n 81, at 767.
} 
constitutional meaning. ${ }^{143}$ Despite this distinction, the practical effect of this approach upon the enforcement of the right remains unclear.

The absence of a categorical approach to expression has not precluded Canadian courts' adoption of a lesser standard of protection for commercial expression. In Rocket $v$ Royal College of Dental Surgeons (Ontario) the Supreme Court held that a "sensitive, caseoriented approach" towards assessing the constitutionality of regulations under s 1 of the Charter permitted consideration of the expression's commercial nature. ${ }^{144}$ This analysis allowed the Court to give effect to the fact that "not all expression is equally worthy of protection." 145 This broad approach was considered necessary, as the variable policy considerations in commercial expression cases meant it was inappropriate to adopt a standardised test of constitutionality. ${ }^{146}$

Irwin Toy Ltd v Quebec (Attorney General) was the first case to reaffirm the conclusions in Ford in the context of pure commercial expression. ${ }^{147}$ However, despite establishing that the passage of the Quebec Consumer Protection Act $1978^{148}$ violated the plaintiff advertiser's freedom of expression, ${ }^{149}$ Irwin Toy undoubtedly supports greater legislative discretion in regulating commercial expression. In applying the Oakes test, the Court concluded that a total ban on all advertising directed at children was commensurate with the legislature's "pressing and substantial" goal of limiting the effects of advertising upon children. ${ }^{150}$ The limited scrutiny to which these regulations were subject has led the case to be described as a low point for the rights of advertisers. ${ }^{151}$

\footnotetext{
143 At 755-756.

${ }^{144}$ Rocket v Royal College of Dental Surgeons (Ontario) [1990] 2 SCR 232 at [30].

145 At [30], citing Edmonton Journal v Alberta (Attorney General) [1989] 2 SCR 1326.

146 At [33]-[34].

${ }^{147}$ Irwin Toy, above n 72, at [42].

${ }^{148}$ Quebec Consumer Protection Act 1978 RS Q c P-40.1.

${ }^{149}$ Irwin Toy, above n 72, at [56]-[57].

${ }^{150}$ At [88]-[89].

${ }^{151}$ See Dubick, above n 68, at 107.
} 
This is not to suggest that Canadian legislators enjoy an unfettered discretion to regulate. In RJR-MacDonald Inc $v$ Canada (Attorney General) the Supreme Court found that advertising restrictions contained within the Tobacco Products Control Act ${ }^{152}$ unreasonably impinged upon tobacco manufacturers' freedom of expression. ${ }^{153}$ Though conscious of commercial expression's reduced protection, ${ }^{154}$ the Court considered Parliament to have provided insufficient justification for its regulations. ${ }^{155}$ The informational benefits conveyed by product advertising underscored the legislature's inability to excessively regulate. ${ }^{156}$ The Court's subsequent decision in Canada (Attorney General) v JTIMacDonald Corp, ${ }^{157}$ in which amended tobacco advertising regulations were upheld, illustrates that, whilst the legislature remains competent to regulate expression, such regulations must be reasonable and demonstrably justified. ${ }^{158}$

Both Canadian and American jurisprudence confers a limited form of constitutional protection upon commercial expression. Given the similarity between the tests in Oakes and Central Hudson for assessing the constitutionality of free speech restrictions, the Canadian courts' refusal to adopt a specific category of commercial speech has had little practical impact. ${ }^{159}$ Despite their failure to establish a substantial basis for commercial expression, both jurisdictions have ultimately accepted a level of quasi-protection, albeit one that admits a degree of deference to potential regulators. ${ }^{160}$ Regardless, both approaches serve as helpful comparators when discussing the treatment of commercial expression within New Zealand's own constitutional setting.

\footnotetext{
${ }^{152}$ Tobacco Products Control Act SC 1998 c 20.

${ }^{153}$ RJR-MacDonald, above n 75.

${ }^{154}$ At [175] per McLachlin J.

${ }^{155}$ At [163] per McLachlin J.

${ }^{156}$ At [170] per McLachlin J.

${ }^{157}$ Canada (Attorney General) v JTI-MacDonald Corp [2007] 2 SCR 610.

${ }^{158}$ See Dubick, above n 68, at 130.

${ }^{159}$ See Shiner, above n 62, at 91.

${ }^{160}$ See Shiner, above n 62, at 93. This is particularly so in the case of advertising, see Munro, above n 60, at 143.
} 


\section{New Zealand}

Unlike Canada and the United States, the New Zealand judiciary has so far failed to establish a substantial jurisprudence in the area of commercial expression. The courts' adoption of a liberal interpretation of the right to freedom of expression, however, suggests a more inclusive approach towards commercial expression. In Moonen v Film \& Literature Board of Review, Tipping J construed 'expression' as being "as wide as human thought and imagination." 161 This broad definition of expression has resulted in a general acceptance that commercial expression is within the scope of constitutional protection afforded by s 14 of the New Zealand Bill of Rights Act. ${ }^{162}$

Despite this protection, New Zealand's extant jurisprudence suggests support for commercial speech restrictions in the context of public health. In a decision relating to the proscription of tobacco advertising under the Smoke-free Environments Act 1990, ${ }^{163}$ the District Court in Director-General of Health v Rothmans of Paul Mall (New Zealand) Ltd considered the expression of tobacco manufacturers had been justifiably limited under the New Zealand Bill of Rights Act. ${ }^{164}$ The Court held that where, as in the Smoke-free Environments Act, the legislature has explicitly stated the values upon which the relevant limit is based, the harm caused by an advertising ban must be construed narrowly. ${ }^{165}$ Despite its conclusions, however, the Court remained conscious of the need to ensure that the means used to protect the desired objective were proportionate. ${ }^{166}$

New Zealand's existing jurisprudence exhibits a number of similarities to the Canadian approach to commercial expression. In adopting a broad definition of expression under the New Zealand Bill of Rights Act, New Zealand courts have accepted a level of prima facie

\footnotetext{
${ }^{161}$ Moonen v Film \& Literature Board of Review [2000] 2 NZLR 9 (CA) at [15] per Tipping J.

162 See Andrew Butler and Petra Butler The New Zealand Bill of Rights Act: A Commentary (LexisNexis, Wellington, 2005) at [13.7.3].

163 See Smoke-free Environments Act 1990, ss 22-23.

${ }^{164}$ Director-General of Health v Rothmans of Paul Mall (New Zealand) Ltd [1996] DCR 353 (DC) at 360 [Rothmans].

165 Rothmans, above n 164, at 360.

166 Rothmans, above n 164, at 360.
} 
constitutional protection for commercial expression. However, the courts' approach to legislative restrictions upon such expression suggests a greater leniency in circumstances of pressing public concern. Though the courts' approach towards assessing the constitutionality of legislative restrictions upon free expression will be discussed later in this paper, ${ }^{167}$ the fact remains that New Zealand's jurisprudence admits a greater capacity to regulate commercial expression. Such an approach therefore supports more stringent regulation of children's food and beverage advertising in New Zealand.

\section{Summary}

An assessment of the theoretical justifications raised in support of the commercial expression doctrine reveals a number of inconsistencies between commercial expression and the core values underlying free speech protection. These inconsistencies have informed subsequent judicial developments in this area. A comparative analysis of the differing approaches to commercial expression within free speech jurisprudence illustrates that these theoretical considerations have resulted in a lower level of constitutional protection for commercial expression. The evidence of a greater willingness to permit regulations constraining commercial expression may thereby justify more stringent regulation of unhealthy food advertising that targets children.

\section{Advertising Regulation in New Zealand}

Food and beverage advertising is repeatedly cited as an important target for anti-obesity policies. Despite this, the New Zealand Government has so far refused to contemplate statutory intervention. ${ }^{168}$ Before considering the possibility of reform, an analysis of the existing regulatory framework is required to assess its compatibility with a public health approach. This analysis highlights the Government's evident preference for a selfregulatory framework and the resultant absence of specific legislation concerning food advertising. A review of this self-regulatory regime demonstrates that, despite attempts by

\footnotetext{
167 See Part VI.

${ }^{168}$ See Ben Heather "Obesity epidemic at 'crisis' point" (9 June 2014) Stuff.co.nz <www.stuff.co.nz>.
} 
self-regulatory institutions to allay the need for government intervention, there remains scope for stronger government regulation of children's food and beverage advertising.

\section{A Legislative Controls on Advertising}

There is currently no legislative framework that specifically regulates the marketing of foods and non-alcoholic beverages in New Zealand. There are, however, a number of statutes controlling advertising content generally. Food and beverage manufacturers remain subject to general consumer protection legislation, such as the Fair Trading Act 1986 and the Consumer Guarantees Act 1993. This legislation is largely predicated upon protecting consumers in the course of business-to-consumer interaction. Sections 9 and 10 of the Fair Trading Act proscribe misleading and deceptive conduct in the course of trade. Similarly, s 9 of the Consumer Guarantees Act provides that goods supplied to consumers must be consistent with the seller's description of them.

One provision that may be applicable to the promotion of unhealthy foods is s $12 \mathrm{~A}$ of the Fair Trading Act. This section prohibits the making of unsubstantiated representations in trade, regardless of whether they are misleading or deceptive. ${ }^{169}$ As it was only introduced in June 2014, the section's scope remains untested. ${ }^{170}$ Its focus upon statements made without reasonable grounds suggests it could be extended to marketing that irresponsibly emphasises healthful product features without due regard to products' other unhealthy characteristics. ${ }^{171}$ The section does not extend, however, to 'puffery' within advertising that a consumer would not expect to be substantiated. ${ }^{172}$ There consequently exists no legislation regulating advertising that, whilst not objectively misleading, remains emotionally persuasive to vulnerable consumers.

\footnotetext{
${ }^{169}$ Fair Trading Act 1986, s 12A.

${ }^{170} \mathrm{~S}$ 12A was inserted, as from 17 June 2014, by s 10 of the Fair Trading Act Amendment Act 2013.

${ }^{171}$ See Thomas Gault (ed) Gault on Commercial Law (online looseleaf ed, Westlaw NZ) at [FTA12A.04].

${ }^{172}$ Commerce Commission "Unsubstantiated Representations” (December 2013) <www.comcom.govt.nz>.
} 
This consumer protection legislation is also supplemented by a range of legislation regulating the advertising of particular products. ${ }^{173}$ The most pertinent example of productspecific advertising regulation is the comprehensive regulatory framework for tobacco advertising established by the Smoke-free Environments Act 1990. Subject to limited statutory authorisation, no person may publish or arrange to have published a tobacco product advertisement. ${ }^{174}$ The Act's broad interpretation of 'publish' requires the ban's application to all media. ${ }^{175}$ Perhaps informatively for future regulations concerning food and beverage advertising, the Act's stated purposes include the regulation of tobacco marketing as a means of reducing social approval for, and use of, harmful tobacco products. ${ }^{176}$ As discussed earlier in this paper, the Act's specific focus upon reducing the harms associated with tobacco use has had important ramifications for the constitutionality of its restrictions upon tobacco advertisers' expression. ${ }^{177}$

The regulatory context surrounding tobacco advertising differs markedly from that relating to food and beverages. Despite this, the regulation of tobacco marketing remains relevant when assessing the constitutionality of potential restrictions upon food advertising. This paper therefore returns to address the tobacco exemplar when considering the constitutionality of a ban on the advertising of unhealthy foods to children under the New Zealand Bill of Rights Act.

\section{$B \quad$ Industry Self-Regulation}

\section{$1 \quad$ Advertising codes and scheduling}

Subject to the aforementioned statutory exceptions, the New Zealand advertising industry is almost exclusively self-regulating. The Advertising Standards Authority (ASA), an

173 See for example Financial Markets Conduct Act 2013, pts 2-3; and Sale and Supply of Alcohol Act 2012, s 237.

${ }^{174}$ Smoke-free Environments Act 1990, s 22.

175 Smoke-free Environments Act 1990, s 2(1).

${ }^{176}$ Smoke-free Environments Act 1990, ss 3A and 21.

177 See Part III. 
organisation comprising representatives of the New Zealand advertising industry, ${ }^{178}$ regulates advertising by way of non-statutory Codes of Practice. These codes represent "the rules by which all advertisements in all media should comply." ${ }^{179}$ Children's food and beverage advertising was traditionally regulated through two separate codes, the Code for Advertising of Food and the Code for Advertising to Children. ${ }^{180}$ Following an extensive review of the codes' suitability to regulating children's food advertisements, ${ }^{181}$ in 2010 the ASA introduced the Children's Code for Advertising Food (Children's Code). ${ }^{182}$ The Children's Code defines children as anyone under the age of 14, and provides guidelines consistent with its requirement that advertisers uphold a high standard of social responsibility. ${ }^{183}$ These guidelines are structured around three core principles: ${ }^{184}$

Principle 1 - Advertisements should be prepared with and observe a high standard of social responsibility to consumers.

Principle 2 - Advertisements should not mislead or deceive or be likely to mislead or deceive children.

Principle 3 - Persons or characters of appeal to children should not be used to promote food in a manner that undermines a healthy diet.

Pursuant to these principles, the Children's Code provides guidelines relating to nutritional claims, ${ }^{185}$ the manner in which food is presented $^{186}$ and product endorsements and promotions. ${ }^{187}$ In particular, advertising should not encourage the consumption of food in

\footnotetext{
178 Advertising Standards Authority "Advertising Standards Authority Inc" <www.asa.co.nz $>$.

179 Advertising Standards Authority "The Advertising Standards Authority" <www.asa.co.nz $>$.

${ }^{180}$ See Advertising Standards Authority "Code for Advertising of Food" <www.asa.co.nz>; and Advertising Standards Authority "Code for Advertising to Children" <www.asa.co.nz>.

${ }^{181}$ Advertising Standards Authority Final Report on the Review of the Code for Advertising to Children and the Code for Advertising of Food (March 2010). See Sharron Bowers, Louise Signal and Gabrielle Jenkin Does Current Industry Self-Regulation of Food Marketing in New Zealand Protect Children from Exposure to Unhealthy Food Advertising? (Otago University Health Promotion and Policy Research Unit, 2012) at 6.

182 See Advertising Standards Authority “Children's Code for Advertising Food” <www.asa.co.nz>.

183 Advertising Standards Authority, above n 182.

${ }^{184}$ Advertising Standards Authority, above n 182.

185 Advertising Standards Authority, above n 182, guidelines 2(c), 2(g), and 2(h).

${ }^{186}$ Advertising Standards Authority, above n 182, guidelines 1(a)-1(j).

187 Advertising Standards Authority, above n 182, guidelines 2(e)-2(f).
} 
a manner inconsistent with the Ministry of Health's nutritional guidelines. ${ }^{188}$ Like many self-regulatory regimes, the Children's Code specifically acknowledges children's vulnerability to marketing communications. ${ }^{189}$ Despite this, the Code fails to provide guidelines restricting the scheduling of advertisements during children's programming. ${ }^{190}$

The ASA's Codes of Practice are further supplemented by specific rules governing broadcast advertising on free-to-air (FTA) television. FTA broadcasters have voluntarily submitted to scheduling restrictions through the ThinkTV Code. ${ }^{191}$ The Code proscribes all advertisements during pre-school children's programming, whilst restricting advertising during school-age children's programming to a maximum of 10 minutes per hour. ${ }^{192}$ The Code defines 'school-age children' as children between the ages of five and $13 .{ }^{193}$ Preschool children's programming is generally defined as the period from 6 am - 10 am, with an intervening period of school-age children's programming from 7 am -8.30 am, during which limited advertising is permitted. ${ }^{194}$ During afternoon slots, pre-school programming is defined as being from $2 \mathrm{pm}-3 \mathrm{pm}$, with school-age programming extending further until $5 \mathrm{pm} .{ }^{195}$ Though evident of an increased appreciation for the need to reduce children's advertising exposure, the narrow scope of these restrictions suggests children are likely to remain subject to high levels of exposure during adult programming.

In addition to the ThinkTV Code's scheduling restrictions, broadcast advertising is also subject to screening by the Commercial Approvals Bureau (CAB). The CAB screens all advertisements prior to broadcast to ensure consistency with the ASA's codes. ${ }^{196}$ Under

\footnotetext{
188 See Ministry of Health "Food and Nutrition Guidelines to Healthy Children and Young People (Aged 218 years): A Background Paper" (2012)<www.health.govt.nz>.

189 Advertising Standards Authority, above n 182, guidelines 2(a)-(b).

${ }^{190}$ See generally Advertising Standards Authority, above n 181.

191 See ThinkTV "Advertising on Television: Getting it Right for Children" (March 2011) <www.thinktv.co.nz> at 3.

192 ThinkTV, above n 191, at 3.

193 ThinkTV “The Children's Television Policies: Advertising in Pre-School and School-Age Children's Television Programming Times" (March 2011) <www.thinktv.co.nz>.

194 ThinkTV, above n 193, at 1.

195 ThinkTV, above n 193, at 1.

196 ThinkTV, above n 191, at 3.
} 
the ThinkTV Code, the $\mathrm{CAB}$ also administers a specific advertising classification for children's food (CF classification). Applicable to all broadcast advertising during schoolage children's programming, the CF classification assesses the healthfulness of advertised foods using both the Ministry of Health's Food and Beverage Classification System (FBCS) and Food Standards Australia New Zealand's Nutrient Profiling Model (FSANZ Model). ${ }^{197}$ The FBCS categorises food and beverage advertisements according to a tripartite classification system. Using a nutrient profiling system, foods are classified as either 'everyday', 'sometimes' or 'occasional'. ${ }^{198}$ Both everyday and sometimes foods are considered fit for broadcast during school-age children's programming. ${ }^{199}$ Occasional foods are those that should only be consumed every few months. These foods are therefore required to satisfy the stricter requirements of the FSANZ Model before the CAB will approve their screening. ${ }^{200}$ Though this pre-screening process represents a positive development, later analysis will demonstrate that the loose nutritional guidelines adopted, and the limited range of programming to which they are applied, have limited the regime's effectiveness in serving public health objectives.

\section{Compliance and enforcement}

The ASA's system of enforcement is entirely reactive. Enforcement of the ASA's codes is reliant upon public complaints of an alleged breach to the Advertising Standards Complaints Board (ASCB), the administrative body tasked with adjudicating upon advertising complaints. ${ }^{201}$ Any decision of the ASCB is then appealable to the Advertising Standards Complaints Appeal Board (ASCAB) ${ }^{202}$ In the event that a complaint is upheld, a request is made of the advertiser to withdraw the advertisement. Despite the absence of

\footnotetext{
197 ThinkTV, above n 191, at 5.

198 ThinkTV, above n 191, at 5.

199 ThinkTV, above n 191, at 5.

200 ThinkTV, above n 191, at 5.

201 Advertising Standards Authority “Advertising Standards Complaints Board” <www.asa.co.nz $>$.

${ }^{202}$ Advertising Standards Authority "Decision Process" <www.asa.co.nz>.
} 
any penalties for non-compliance, no advertiser has yet failed to comply with this request. $^{203}$

The ASA's success in limiting the prevalence of unhealthy children's advertising through the Children's Code is unclear. Since its implementation, only two complaints have been considered by the ASCB, both of which have been denied. ${ }^{204}$ This limited number of complaints paints an uncertain picture of the system's success. One possibility is that the use of detailed guidelines and pre-screening has substantially reduced the number of advertisements in breach of the ASA's Codes of Practice. Alternatively, the absence of complaints may be a function of both a lack of consumer knowledge and the perceived difficulty in making a complaint to the ASCB. ${ }^{205}$ The most compelling suggestion is that the ambiguity inherent within the ASA's codes precludes any reduction in children's exposure to unhealthy food and beverage advertising. ${ }^{206}$ Given the ambiguity and limited scope of the current restrictions, undesirable advertising may simply be passing undetected. Though the current evidence means this cannot be answered definitively, the possibility of such inconsistency between industry self-regulation and reduced volumes of unhealthy food advertising begs the question whether a government-led approach informed by public health considerations would be more effective in limiting children's advertising exposure.

\section{Summary}

The New Zealand Government's extant refusal to regulate food and beverage advertising arises from its stated confidence in the existing self-regulatory framework. ${ }^{207}$ The industry has made concerted attempts to ameliorate the harms posed by unhealthy food advertising

\footnotetext{
203 Louise Thornley, Louise Signal and George Thomson "Does industry regulation of food advertising protect child rights?” (2010) 20(1) Critical Public Health 25 at 27.

204 Bowers, Signal and Jenkin, above n 181, at 17.

205 See Corinna Hawkes Marketing Food to Children: the Global Regulatory Environment (World Health Organisation, 2004) at 17.

206 See generally Corinna Hawkes "Self-regulation of food advertising: what it can, could and cannot do to discourage unhealthy eating habits among children" (2005) 30 British Nutrition Foundation Nutrition Bulletin 374.

${ }^{207}$ See Heather, above n 168.
} 
to children. However, the numerous gaps evident within its framework suggest the need for a regulatory approach more suited to the achievement of public health objectives. Though the deficiencies of the framework will be elaborated upon later in this paper, ${ }^{208}$ this discussion has sufficiently highlighted the need to evaluate possible alternatives to the self-regulation of food and beverage advertising.

\section{$V$ Comparative Approaches to Advertising Regulation}

As evident from New Zealand's existing regulatory framework, advertising regulation is predominantly seen by legislators as the preserve of the advertising industry itself. ${ }^{209}$ Despite this, there remain notable examples of governments' willingness to intervene in the regulation of advertising. The regulatory frameworks of the United Kingdom, Sweden and Quebec help demonstrate the alternatives available to legislators. This Part outlines the differing regulatory approaches within these jurisdictions and, where possible, attempts to comment upon their effectiveness. Though certain issues remain inherent within each approach, an understanding of their operation helps inform the development of any future advertising restrictions in New Zealand.

\section{A Advertising Regulation in Europe}

\section{Broadcasting and the European Directives}

The European Parliament provides extensive guidelines for commercial advertising regulation within the European Union. In addition to prescribing general consumer protection laws, ${ }^{210}$ these guidelines also provide specifically for broadcasting regulations. The Television Without Frontiers Directive (TVWF Directive) prescribes minimum

\footnotetext{
${ }^{208}$ See Part VI.

${ }^{209}$ See Hawkes, above n 10, at 1964.

${ }^{210}$ See Directive 2005/29/EC of the European Parliament and of the Council of 11 May 2005 concerning unfair business-to-consumer commercial practices in the internal market and amending Council Directive 84/450/EEC, Directives 97/7/EC, 98/27/EC and 2002/65/EC of the European Parliament and of the Council and Regulation (EC) No 2006/2004 of the European Parliament and of the Council [2005] OJ L 149/22 ('Unfair Commercial Practices Directive').
} 
standards for broadcasting that must be incorporated within the domestic legislation of all Member States. ${ }^{211}$ Specifically, it seeks to regulate advertising that encourages "behaviour prejudicial to health and safety", ${ }^{212}$ and that which causes "moral or physical detriment to minors." 213 As these are only minimum standards, Member States remain free to impose stricter rules upon broadcasters subject to their jurisdiction. ${ }^{214}$

The terms of the TVWF Directive are supplemented by the Audiovisual Media Services Directive (AVMS Directive). ${ }^{215}$ Article 9, which governs children's food advertising, specifically prescribes the development of regulations moderating advertising's effects upon children. ${ }^{216}$ The AVMS Directive's effectiveness, however, is constrained by its failure to include a commonly held definition of both 'children' and 'unhealthy' foods. ${ }^{217}$ Its provisions are therefore susceptible to vastly differing interpretations within domestic legislation. $^{218}$

The primary deficiency of both broadcasting directives lies in their inability to effectively regulate the cross-border transmission of broadcast advertising. Both directives operate on the basis of the 'state of establishment' principle, which holds that broadcasters need only abide by the legislation of the Member State from which they are transmitted. ${ }^{219}$ States'

\footnotetext{
${ }^{211}$ Directive 2007/65/EC of the European Parliament and of the Council of 11 December 2007 amending Council Directive 89/552/EEC on the coordination of certain provisions laid down by law, regulation or administrative action in Member States concerning the pursuit of television broadcasting activities [2007] OJ L 332/27 ('Television Without Frontiers Directive'); see A Garde "Food advertising and obesity prevention: what role for the European Union?” (2008) 31(1) Journal of Consumer Policy 25 at 32.

${ }^{212}$ Television Without Frontiers Directive [2007] OJ L 332/27, art 12.

${ }^{213}$ Television Without Frontiers Directive [2007] OJ L 332/27, art 16.

${ }^{214}$ Television Without Frontiers Directive [2007] OJ L 332/27, art 3.

215 Directive 2010/13/EU of the European Parliament and of the Council of 10 March 2010 on the coordination of certain provisions laid down by law, regulation or administrative action in Member States concerning the provision of audiovisual media services [2010] OJ L 95/1 ('Audiovisual Media Services Directive').

${ }^{216}$ Audiovisual Media Services Directive [2010] OJ L 95/1, art 9(2).

217 Almudena Gonzalez del Valle "A Reflection on European Regulation of Television Advertising to Children" (2013) 32(2) Communication Research Trends 19 at 21.

${ }^{218}$ del Valle, above $\mathrm{n} 217$, at 21.

${ }^{219}$ Garde, above n 211, at 32.
} 
obligations to respect this principle have since been confirmed by the Court of Justice of the European Union, which established that states' domestic advertising restrictions are inapplicable to extra-territorial broadcasts. ${ }^{220}$ These restrictions have therefore limited the ability of European states to independently regulate against the harmful effects of unhealthy food advertising within their respective territories. ${ }^{221}$

\section{United Kingdom}

Advertising regulation within the United Kingdom is governed by a co-regulatory framework involving both statutory and industry bodies. The predominant institution is the United Kingdom Office of Communications (Ofcom). Under the Communications Act 2003, Ofcom is mandated to set and review national broadcasting standards. ${ }^{222}$ These standards are based on a set of regulatory objectives, which include the object of protecting persons under the age of $18 .{ }^{223}$ In pursuance of these objectives, the Communications Act authorises Ofcom to draft standards relating to both the timing and content of advertisements. $^{224}$

The existing co-regulatory framework arose specifically from governmental concerns regarding "the nature and balance of food and beverage advertising." 225 As the body responsible for the publication of advertising standards, Ofcom was engaged to strengthen

the existing rules on the advertising of food and drink products to children. ${ }^{226}$ Following an extensive consultation process, the following measures were adopted:227

\footnotetext{
${ }^{220}$ Case C-34/95 Konsumentombudsmannen (KO) v De Agostini (Svenska) Förlag AB [1997] ECR I-3843.

${ }^{221}$ Garde, above n 211, at 41.

222 Communications Act 2003 (UK), s 319.

${ }^{223}$ Communications Act 2003 (UK), s 319(2)(a).

${ }^{224}$ Communications Act 2003 (UK), ss 321(1)(b) and 322.

${ }^{225}$ United Kingdom Office of Communications HFSS Advertising Restrictions: Final Review (July 2010) at 1.

${ }^{226}$ United Kingdom Office of Communications, above n 225, at 1.

227 United Kingdom Office of Communications Television Advertising of Food and Drink Products to Children: Final Statement (February 2007) at 3.
} 
(a) A ban on high fat, sugar and salt (HFSS) product advertisements in or around programmes made for children (including pre-school children);

(b) a ban on HFSS advertisements in or around programmes likely to be of particular appeal to children aged four to 15 ; and

(c) a ban on sponsorship in the name of HFSS products in programmes of particular appeal to children.

The review also led to revised content rules applicable to all advertising irrespective of scheduling times. These rules relate primarily to the use of marketing techniques likely to appeal to children. In particular, the revised rules speak to the use of popular figures, promotional offers and marketing techniques appealing to parent pressure. ${ }^{228}$

These revised regulations have required the adoption of universal definitions for both 'unhealthy foods' and 'children's programming'. Food and drink products are assessed as HFSS using the United Kingdom Food Safety Authority's nutrient profiling scheme, which screens products with a high level of undesirable nutrient content. ${ }^{229}$ Children's programming is defined using a combination of dedicated children's channels and children's television slots on the main public service broadcasting channels (PSB channels). ${ }^{230}$ Although these slots vary with each channel, they focus predominantly upon the period from $6 \mathrm{am}-11 \mathrm{am} .^{231}$ Only one channel has afternoon programming considered as a children's slot, ${ }^{232}$ with all other programming considered adult airtime. ${ }^{233}$

Under the co-regulatory framework, Ofcom has contracted out its regulatory function with regard to broadcast advertising. ${ }^{234}$ In accordance with this arrangement, the advertising industry's code-making body, the Broadcast Committee for Advertising Practice (BCAP)

\footnotetext{
${ }^{228}$ United Kingdom Office of Communications, above n 227, at 48-53.

229 See United Kingdom Food Standards Authority Nutrient Profiling Technical Guidance (April 2009); and United Kingdom Office of Communications, above n 227, at 3.

${ }^{230}$ United Kingdom Office of Communications, above n 225, at 57.

${ }^{231}$ United Kingdom Office of Communications, above n 225, at 57.

232 United Kingdom Office of Communications, above n 225, at 57.

${ }^{233}$ United Kingdom Office of Communications, above n 225, at 57.

${ }^{234}$ See The Contracting Out (Functions relating to Broadcast Advertising) and Specification of Relevant Functions Order 2004 (UK); and United Kingdom Office of Communications, above n 227, at 8.
} 
is responsible for the implementation of the revised standards within the United Kingdom Code of Broadcast Advertising. ${ }^{235}$ Another industry body, the United Kingdom Advertising Standards Authority (UKASA), is responsible for the monitoring and enforcement of advertisers' compliance with the Code. ${ }^{236}$ Notwithstanding this delegated responsibility, the functions of both the UKASA and BCAP are exercised subject to Ofcom's agreement. ${ }^{237}$

Despite being the first country to introduce statutory scheduling rules targeting children's food advertisements, ${ }^{238}$ the United Kingdom's co-regulatory framework has enjoyed a mixed reception. In its review of the system in 2010, Ofcom suggested that its scheduling restrictions had reduced children's exposure to HFSS advertisements by 37 per cent. ${ }^{239}$ The accuracy of these figures has been contested, however, with multiple studies citing an increase in the level of children's exposure subsequent to the ban's implementation. ${ }^{240}$

The primary criticism levelled at the scheme concerns its limited scope. Though Ofcom's restrictions have enjoyed relative success with broadcast advertising, the effectiveness of the ban has been limited across other media. Evidence suggests that, despite the scheme's effect in reducing advertisers' outlay upon food advertising within children's television, advertising expenditure across all media rose during the same period. ${ }^{241}$ Furthermore, the restriction's limited focus upon children's programming inhibits its effectiveness in

\footnotetext{
${ }^{235}$ United Kingdom Office of Communications, above n 227, at 4. See Broadcast Committee of Advertising Practice "BCAP Code: The UK Code of Broadcast Advertising" (1 September 2010) <http://www.cap.org.uk>.

${ }^{236}$ United Kingdom Office of Communications, above n 227, at 4.

${ }^{237}$ Broadcast Committee of Advertising Practice, above n 235, at 131.

238 Jean Adams and others "Effect of Restrictions on Television Food Advertising to Children on Exposure to Advertisements for 'Less Healthy' Foods: Repeat Cross-Sectional Study” (2012) 7(2) PLOS One 1 at 2.

${ }^{239}$ United Kingdom Office of Communications, above n 225, at 3.

${ }^{240}$ See Adams and others, above n 238, at 4; and del Valle, above n 217, at 22.

241 United Kingdom Department of Health Changes in Food and Drink Advertising and Promotion to Children: A Report Outlining the Nature and Balance of Food and Drink Advertising and Promotion to Children (2008), as cited in Goris and others, above n 50, at 1009.
} 
reducing children's exposure during adult airtime. ${ }^{242}$ When coupled with the TVWF Directive's effect in proscribing the restriction of extra-territorial broadcasts, the width of the United Kingdom's regulations becomes considerably narrowed. This suggests a more comprehensive approach to scheduling and media coverage is necessary to effectively reduce children's exposure to HFSS advertising.

\section{Sweden}

Unlike the United Kingdom, Sweden's regulatory framework for children's advertising did not arise specifically out of concerns regarding food-related marketing. Instead, Swedish initiatives to restrict advertising to children have stemmed from children's accepted vulnerability to marketing communications. ${ }^{243}$ Swedish society places considerable emphasis upon the need to support weaker citizens in their capacity as consumers. ${ }^{244}$ Consumer protection within Sweden is therefore viewed as an important responsibility of the state. ${ }^{245}$

The Swedish Marketing Practices Act governs all advertising in Sweden, regardless of its target audience or the media used. ${ }^{246}$ The Act focuses upon encouraging good marketing practice, ${ }^{247}$ pursuant to which it requires that marketing be trustworthy and not misleading. ${ }^{248}$ In addition to establishing a framework of general rules for marketers, the Act provides a set of specific rules relating to certain marketing activities. ${ }^{249}$

\footnotetext{
242 Jason Halford and others "Television Food Advertising to Children: A Global Perspective" (2010) 100(9) American Journal of Public Health 1730 at 1735.

${ }^{243}$ Martin Caraher, Jane Landon and Kath Dalmeny "Television Advertising and Children: Lessons from Policy Development” (2005) 9(5) Public Health Nutrition 596 at 600.

${ }^{244}$ Ulf Bernitz "Consumer Protection: Aims, Methods, and Trends in Swedish Consumer Law" (1976) $20 \mathrm{Sc}$ St L 12 at 14 and 22.

${ }^{245}$ Michael Plogell and Jesper Sundstrom "Advertising to children in Sweden" (2004) 5(2) Advertising \& Marketing to Children 65 at 65.

${ }^{246}$ Marketing Practices Act (Sweden) No 2008:486. See Plogell and Sundstrom, above n 245, at 65.

${ }^{247}$ Marketing Practices Act (Sweden) No 2008:486, s 5.

${ }^{248}$ Marketing Practices Act (Sweden) No 2008:486, ss 8-10.

${ }^{249}$ See Plogell and Sundstrom, above n 245, at 65.
} 
The general provisions of the Marketing Practices Act are supplemented by specific regulations governing children's television advertising. The Swedish Radio and Television Law prohibits all television advertising during programmes directed at children under 12. ${ }^{250}$ Whether a particular commercial is directed at children involves consideration of the characteristics of the product, the commercial's design and the time at which it is broadcast. $^{251}$ The ban is rigorously enforced, with the Consumer Ombudsman holding significant powers to ensure advertisers' compliance. ${ }^{252}$ Regulatory enforcement also benefits from the prevailing attitude to consumer protection within Swedish society, with almost 90 per cent of Swedish advertising professionals supporting a ban on children's advertising. ${ }^{253}$

Regardless of this success, the Swedish regulatory framework exhibits a number of deficiencies. The Radio and Television Law's vague definition of the phrase "directed at children" has created issues for advertisers, particularly where advertising is designed to appeal to both adults and children. ${ }^{254}$ Though advertisers are generally in support of the ban, its inherent uncertainties exert a potential chilling effect upon some advertising. Attempts by enforcement authorities to overcome this problem by adopting a less restrictive approach have resulted in a number of potentially harmful advertisements falling outside the scope of the ban. ${ }^{255}$ Like the United Kingdom, Swedish regulations also suffer from an absence of specific provisions relating to children's internet advertising. ${ }^{256}$ Whilst internet advertising remains subject to the general provisions of the Marketing Practices Act, the growth in internet-based marketing suggests a more comprehensive approach is required.

\footnotetext{
${ }^{250}$ Radio and Television Law (Sweden) No 2010:696, ch 8 s 3.

${ }^{251}$ Plogell and Sundstrom, above n 245, at 66.

252 Obesity Action Coalition Would you like lies with that? Food, Kids and Advertising (October 2007) at 16; and Hawkes, above n 205, at 19.

253 Browne, Biksacky and Frondorf, above n 21, at 116-117.

${ }^{254}$ See Plogell and Sundstrom, above n 245, at 66.

255 See Caraher, Landon and Dalmeny, above n 243, at 600.

${ }^{256}$ See Plogell and Sundstrom, above n 245, at 67.
} 
The primary constraint upon Swedish regulations' effectiveness in reducing children's advertising exposure has been the prevalence of cross-border broadcasting. Sweden, like the United Kingdom, remains subject to the TVWF Directive's 'state of establishment' principle. Given the majority of European states remain willing to abide by the minimum standards prescribed by the Directive, the effectiveness of the Swedish ban stands to be undermined by commercials carried on extra-territorial television broadcasts. ${ }^{257}$ This is reinforced by the fact that only one of the three channels most popular with Swedish children is broadcast from within Sweden. ${ }^{258}$ The absence of an integrated, trans-national approach to broadcast regulation therefore sheds doubt on the potential success of further independently implemented broadcast regulations. ${ }^{259}$

\section{B Quebec}

Unlike other Canadian provinces, in which advertising is exclusively self-regulated, ${ }^{260}$ the Quebecois legislature has specifically legislated for children's advertising protections. Section 248 of the Quebec Consumer Protection Act 1978 prohibits commercial advertising directed at children under the age of $13 .{ }^{261}$ Section 249 provides that, in determining whether an advertisement is targeted at children, account must be taken of the advertisement's context, including the nature of the goods advertised, the manner in which it is presented and the time and place of presentation. ${ }^{262}$ The Quebec Office de la Protection $\mathrm{du}$ Consommateur also promulgates additional guidelines to facilitate marketers'

\footnotetext{
257 See Goris and others, above n 50, at 1009.

${ }^{258}$ Halford and others, above n 242, at 1735.

259 See Matthews and others, above n 10, at 14-15.

260 See generally Advertising Standards Canada "The 14 Clauses of the Canadian Code of Advertising Standards" (August 2014) <www.adstandards.com>; Advertising Standards Canada "Broadcast Code for Advertising to Children - The Code" (August 2014) <www.adstandards.com>; and Canadian Marketing Association "Code of Ethics and Standards of Practice" <www.the-cma.org>. For a general overview of the Canadian self-regulatory framework see Bill Jeffery "The Supreme Court of Canada's Appraisal of the 1980 Ban on Advertising to Children in Quebec: Implications for 'Misleading' Advertising Elsewhere” (2006) 39 Loy LA L Rev 237 at 245.

${ }^{261}$ Quebec Consumer Protection Act 1978 RS Q c P-40.1, s 248.

262 Quebec Consumer Protection Act, s 249.
} 
compliance, ${ }^{263}$ whilst proposed advertisements are subject to proactive review by Quebec's Consumer Ombudsman prior to broadcast. ${ }^{264}$ In the context of television advertising, programming for which children's viewership is greater than 15 per cent is considered children's programming. ${ }^{265}$ Because the legislation requires consideration of both the timing and character of the advertising, however, food and beverage advertisements appealing to children younger than 13 remain permitted during adult programming. ${ }^{266}$

The strength of the Quebecois ban lies in its applicability to a broad range of advertising media. The Consumer Protection Act defines the words 'to advertise' as meaning "to prepare, utilise, distribute, publish or broadcast an advertisement, or to cause it to be distributed, published or broadcast."267 Unlike the other approaches discussed, this definition enables the ban to extend to a range of media. Given the increasing fragmentation of marketing communications, ${ }^{268}$ this suggests the Quebecois ban could be more effective in reducing children's exposure to unhealthy food advertising.

The period of time since the ban's implementation has also afforded opportunities to measure its effect, not only upon advertising exposure, but also upon food consumption behaviours. Studies reveal that the ban has resulted in French-speaking children in Quebec being exposed to a significantly lower percentage of HFSS advertising when compared with English-speaking children in Quebec and Ontario. ${ }^{269}$ The consequences of reduced exposure upon consumption are also marked. A cross-sectional study has suggested young adults in French-speaking Quebecois households with children are 38 per cent less likely

${ }^{263}$ See Quebec Office de la Protection du Consommateur "Advertising Directed at Children under 13 Years of Age: Guide to the Application of Sections 248 and 249 Consumer Protection Act" (10 September 2012) $<$ www.opc.gouv.qc.ca>. The Quebec Office de la Protection du Consommateur is Quebec's Consumer Protection Office.

264 Obesity Action Coalition, above n 252, at 15.

${ }^{265}$ See Quebec Office de la Protection du Consommateur, above n 263, at 26.

266 Monique Potvin Kent, Lise Dubois and Alissa Wanless "A Nutritional Comparison of Foods and Beverages Marketed to Children in Two Advertising Policy Environments” (2012) 20(9) Obesity 1829 at 1830 .

${ }^{267}$ Quebec Consumer Protection Act, s 252.

${ }^{268}$ See Hawkes, above n 10, at 1962.

${ }^{269}$ See Kent, Dubois and Wanless, above n 266, at 1835. 
to purchase fast food in a given week than in Ontario. ${ }^{270}$ When extrapolated to all Frenchspeaking households in Quebec, this suggests that the ban results in 16.8 million fewer fast food meals being sold per year. ${ }^{271}$

The ban has also led to substantial changes in marketing practice. Its primary effect has been to limit advertising expenditure within media covered by the ban. Sources estimate the net loss to Quebec's advertising market from this to be between USD 3.9 million and USD 8.2 million. ${ }^{272}$ There have also been marked changes in commercial content, with commercials intentionally designed to appear less appealing to children. ${ }^{273}$ If the ban's rationale is to ameliorate the effect of advertisements upon children, this re-orientation of marketing efforts towards adults better suited to understanding advertising's intent represents a resounding success.

Notwithstanding this success, Quebec's advertising ban still admits scope for improvement. Its differing effects upon children again demonstrate the issue posed by cross-border transmissions. Canadian federal law prohibits the application of the Quebecois ban to any advertisement broadcast or propagated from outside Quebec. ${ }^{274}$ Furthermore, pursuant to the North American Free Trade Agreement, the moderation by Canadian authorities of cable signals rebroadcast from the United States is prohibited. ${ }^{275}$ The cross-border transmission of unhealthy food advertising, in conjunction with the inherent gaps within its application, therefore minimises the Quebecois ban's effectiveness. It is consequently suggested that as much as 30 per cent of food advertisements featured in Quebec remain targeted at children. ${ }^{276}$ This percentage is much greater for Englishspeaking Quebecois children, who are subjected to cross-border transmissions containing

\footnotetext{
270 See Tirtha Dhar and Kathy Baylis "Fast-Food Consumption and the Ban on Advertising Targeting Children: The Quebec Experience" (2011) 48 Journal of Marketing Research 799 at 809.

${ }^{271}$ Dhar and Baylis, above n 270, at 809.

272 Dhar and Baylis, above n 270, at 802.

${ }^{273}$ Hawkes, above n 10, at 20.

${ }^{274}$ See generally Jeffery, above n 260.

275 North American Free Trade Agreement 32 ILM 289 (signed 17 December 1992, entered into force 1 January 1994), arts 305-306.

276 See Kent, Dubois and Wanless, above n 266, at 1830.
} 
advertisements produced in the English language. ${ }^{277}$ These limits upon the ban's effectiveness are therefore pertinent when considering the likely success of a similar advertising ban within New Zealand.

\section{The Constitutionality of an Advertising Ban for New Zealand}

\section{A A Possible Advertising Ban for New Zealand}

The existing evidence provides sufficient justification to consider the potential for a ban on unhealthy food advertising targeting children. The nature of the ban chosen, however, has substantial repercussions for both its efficacy and its consistency with New Zealand's existing free speech protections. The differing international approaches to advertising regulation provide important lessons in this respect. The limited application of advertising restrictions to non-broadcast media in both Sweden and the United Kingdom patently undermines the regulations' effectiveness in reducing children's advertising exposure. This conclusion suggests a broad regulatory framework is needed to counter the likely substitution effects of a limited advertising ban upon advertising expenditure in new media. ${ }^{278}$ An approach analogous with the Quebecois ban is therefore suggested given its applicability to a range of media. The appropriateness of this suggestion is reinforced by the constitutional similarities between Canada and New Zealand. Furthermore, the Canadian Supreme Court's prior validation of the Quebecois ban as a justified limitation upon free expression should prove informative when considering the constitutionality of a similar ban in New Zealand. ${ }^{279}$

This paper does not, however, suggest a wholesale transplantation of the Quebecois approach. Given the potential cultural disparities between countries, regulations should not

\footnotetext{
${ }^{277}$ See Kent, Dubois and Wanless, above n 266, at 1836; and Dhar and Baylis, above n 270, at 811.

${ }^{278}$ See Maria Morgan and others "A content analysis of children's television advertising: focus on food and oral health" (2008) 12(6) Public Health Nutrition 748 at 754; and Henry Saffer and Frank Chaloupka "The effect of tobacco advertising bans on tobacco consumption" (2000) 19 Journal of Health Economics 1117 at $1122-1124$.

${ }^{279}$ See Irwin Toy, above n 72, at [88].
} 
be imported haphazardly. ${ }^{280}$ A more tailored approach to the regulation of children's food and beverage advertising than that used in Quebec is therefore required. A ban focused upon children under the age of 13 is consistent with both scientific and industry understandings of children's vulnerability. ${ }^{281}$ Though international guidelines advocate the regulation of all commercial promotions, ${ }^{282}$ any approach should be tailored more specifically to obesity-related concerns. This paper therefore suggests a ban prohibiting all advertising of unhealthy food and beverages directed at children under the age of 13 years. This narrower approach would minimise the restrictions imposed upon freedom of expression. The suggested ban focuses only upon advertisements promoting unhealthy foods and beverages. The use of the stricter FSANZ nutrient profiling guidelines should be retained, ${ }^{283}$ with all advertising either aimed at children or broadcast during children's programming to be consistent with its nutritional standards. When attempting to establish whether advertising is targeted at children, the advice provided within s 249 of the Quebec Consumer Protection Act and its supplementary guidelines is informative. ${ }^{284}$ However, given the existing Quebecois regime's failure to regulate children's advertising during adult programming, the suggested ban would extend to all advertising designed to appeal to children, regardless of the time shown.

Having developed the structure for a potential ban, its consistency with the existing constitutional protections for free expression can now be considered. Given the broad definition of expression adopted for the purposes of the New Zealand Bill of Rights Act, ${ }^{285}$ commercial expression is considered within the purview of constitutional protection. ${ }^{286}$ The restriction of advertising as a form of expression therefore limits the right to free

\footnotetext{
${ }^{280}$ See Susy Frankel "New Zealand: Regulation of Tobacco, Alcohol and Unhealthy Food in New Zealand and Coordinating the Trans-Tasman Relationship" in Tania Voon, Andrew D Mitchell and Jonathan Liberman (eds) Regulating Tobacco, Alcohol and Unhealthy Foods: The Legal Issues (Routledge, Oxford, 2014) 296 at 304.

${ }^{281}$ See Part II. See also Swinburn and others, above n 8, at 883.

282 See Swinburn and others, above n 8, at 883.

283 See ThinkTV, above n 191, at 3.

${ }^{284}$ See Quebec Consumer Protection Act 1978 RS Q c P-40.1, s 249; and Quebec Office de la Protection du Consommateur, above n 263.

285 See Moonen, above n 161, at [15] per Tipping J.

${ }^{286}$ See Butler and Butler, above n 162, at [13.7.3]; and Rothmans, above n 164, at 360.
} 
expression under s 14. ${ }^{287}$ The Canadian Supreme Court in Irwin Toy Ltd $v$ Quebec (Attorney General) has previously considered that the Quebecois advertising ban represents a demonstrably justified limit upon free expression. ${ }^{288}$ Despite the identical constitutional framework informing this analysis, the Court's conclusions are not directly applicable to the tailored version of the Quebecois ban suggested here. Given 25 years have passed since the decision in Irwin Toy, the changing commercial and media environment suggests a re-evaluation of the ban's constitutionality is appropriate. Moreover, as the Quebecois ban was not informed specifically by public health concerns, a constitutional analysis informed by such considerations is merited. This paper accordingly considers whether the context provided by the burgeoning obesity epidemic enables the ban's justification under s 5 of the New Zealand Bill of Rights Act.

\section{B Is an Advertising Ban a Demonstrably Justified Limit upon Freedom of Expression?}

The right to freedom of expression is not absolute. Section 5 of the New Zealand Bill of Rights Act 1990 provides that "the rights and freedoms contained in this Act may be subject only to such reasonable limits prescribed by law as can be demonstrably justified in a free and democratic society." The New Zealand Supreme Court in $R v$ Hansen, adopting the Canadian approach established in $R v$ Oakes ${ }^{289}$ have structured this analysis under the following headings: ${ }^{290}$

(a) does the limiting measure serve a purpose sufficiently important to justify curtailment of the right or freedom?

(b) (i) is the limiting measure rationally connected with its purpose?

(ii) does the limiting measure impair the right ... no more than is reasonably necessary for sufficient achievement of its purpose?

(iii) is the limit in due proportion to the importance of the objective?

\footnotetext{
${ }^{287}$ New Zealand Bill of Rights Act 1990, s 14.

${ }^{288}$ Irwin Toy, above n 72, at [88]-[89].

${ }^{289} R$ v Oakes, above n 140, at [74].

${ }^{290} R v$ Hansen [2007] NZSC 7, [2007] 3 NZLR 1 at [104] per Tipping J.
} 


\section{$1 \quad$ Prescribed by law?}

Limitations prescribed by law are required to be "identifiable and expressed with sufficient precision in an Act of Parliament. Limits must be neither ad hoc nor arbitrary and their nature and consequences must be clear." ${ }^{, 291}$ Here, the suggested ban confers a discretion upon the adjudicator to consider whether an advertisement targets children. International exemplars have previously revealed the difficulty faced by advertisers in defining 'children' for the purposes of their compliance with statutory prohibitions. ${ }^{292}$ In applying this discretion under the proposed legislation, however, the decision maker is provided with clear guidelines. The provision of additional guidance moulded upon s 249 of the Quebec Consumer Protection Act and its associated guidelines ameliorates any discretionary uncertainty. ${ }^{293}$ Such guidance will thereby enable advertisers to proactively ascertain advertisements' consistency with the legislation.

The proposed regulations also provide clear rules regarding the types of food advertising proscribed. The use of the FSANZ nutrient profiling model is consistent with a public health understanding of healthful nutrition. Moreover, advertisers' argument that the FSANZ model introduces an unacceptable level of uncertainty into the legislation is negated, given its use within the existing voluntary restrictions adopted by FTA broadcasters under the ThinkTV Code. In Irwin Toy, the Canadian Supreme Court considered that the conferral of a discretion in applying the law was legitimate in so far as "the legislature has provided an intelligible standard according to which the [decision maker] must do its work." ${ }^{294}$ Given the current standards are modelled upon those considered by the Court in Irwin Toy, the terms of the proposed ban are sufficiently intelligible to be considered prescribed by law.

\footnotetext{
${ }^{291} R v$ Hansen, above $\mathrm{n} 290$, at [180] per McGrath $\mathrm{J}$.

${ }^{292}$ See Plogell and Sundstrom, above n 245, at 66.

${ }^{293}$ See Quebec Consumer Protection Act 1978 RS Q c P-40.1, s 249; and Quebec Office de la Protection du Consommateur, above n 263. See Part V.

${ }^{294}$ Irwin Toy, above n 72, at [64].
} 
2 Does the limiting measure serve a purpose sufficiently important to justify curtailment of the right or freedom?

When considering the importance of the legislator's objective, the relevant object is that of the infringing measure itself. ${ }^{295}$ To merit justification this objective "must relate to concerns that are pressing and substantial in a free and democratic society." 296 The way in which this objective is framed therefore impacts the limit's subsequent justification. Despite focusing predominantly upon the objective of the limit, Butler and Butler suggest that the objective of the law as a whole remains relevant to determining the limit's own importance. $^{297}$ Though the legislator's objective must be sufficiently pressing, the threshold of importance is considered low. ${ }^{298}$ The courts will typically be hesitant to impugn a purpose considered important by Parliament, particularly on issues of social policy. ${ }^{299}$

The main purpose of a ban on the advertising of unhealthy foods to children is to reduce the harm caused by children's exposure to unhealthy food and beverage advertising. Evidence of this objective's importance is prevalent throughout the international regulatory environment. From a public health perspective, the WHO has consistently reiterated its view that the marketing of unhealthy foods and beverages to children constitutes an international issue. ${ }^{300}$ Its publication of principles guiding the regulation of food and beverage advertising is consistent with the view that responsibility for the obesity epidemic lies at a governmental level. ${ }^{301}$

Children's vulnerability to advertising is also well established. Empirical evidence reveals substantial deficiencies in children's media literacy that result in an inability to accurately

\footnotetext{
${ }^{295}$ RJR-MacDonald, above n 75, at [144] per McLachlin J.

${ }^{296} R v$ Hansen, above $\mathrm{n} 290$, at [203] per McGrath J.

${ }^{297}$ Butler and Butler, above n 162, at [6.11.5].

${ }^{298}$ See Butler and Butler, above n 162, at [6.11.5].

${ }^{299}$ See $R$ v Hansen, above n 290, at [207] per McGrath J.

${ }^{300}$ See World Health Organisation, above n 9, at 9.

${ }^{301}$ See World Health Organisation, above n 9, at 10; and Swinburn and others, above n 8, at 881.
} 
interpret advertising's intent. ${ }^{302}$ This vulnerability is also reflected within international human rights instruments. The United Nations Convention on the Rights of the Child specifically condones regulations that limit rights in order to protect children's interests. ${ }^{303}$ Government intervention on public health grounds is therefore necessary where individuals are incapable of producing desired outcomes themselves. ${ }^{304}$ In Irwin Toy, the Canadian Supreme Court considered the general vulnerability of children to advertising generated a "consensus of concern". 305 The restriction of children's television marketing was consequently seen as a sufficiently important objective. ${ }^{306}$ Though this decision was not concerned with the wider issue of children's obesity, the issue's growing prevalence and its resultant social costs further reinforce the importance of the ban's objective in limiting children's exposure to unhealthy food and beverage advertisements.

\section{Is the limiting measure rationally connected to its purpose?}

The rational connection analysis involves establishing a causal connection between the limit and its intended purpose. ${ }^{307}$ The limit must therefore be "fair and not arbitrary [and] carefully designed to achieve the objective in question". ${ }^{308}$ A ban on the advertising of unhealthy foods and beverages to children is clearly connected to legislators' object of reducing children's exposure to unhealthy food advertising. The effect of the ban is to proscribe the advertising of unhealthy foods to children. Children's exposure to unhealthy food advertising is thus likely to be reduced as a result. Rather than being seen as an arbitrary limit, the contemplated ban represents a logical attempt to ameliorate food marketing's effects upon children.

\footnotetext{
302 See Dixon and others, above n 21, at 212; and Livingstone and Helsper, above n 23, at 562.

${ }^{303}$ United Nations Convention on the Rights of the Child 1577 UNTS 3 (opened for signature 20 November 1989, entered into force 2 September 1990), arts 13 and 17.

304 Thomas R Oliver "The Politics of Public Health Policy” (2006) 27 Annu Rev Public Health 195 at 196.

305 Irwin Toy, above n 72, at [72].

306 At [73]-[74].

${ }^{307}$ RJR-MacDonald, above n 75, at [153] per McLachlin J.

${ }^{308} R v$ Hansen, above n 290, at [204] per McGrath J.
} 
Conversely, though a rational connection exists between an advertising ban and its objective in reducing children's exposure to unhealthy food advertising, there remain issues of causality with the law's wider objective of reducing children's obesity. As discussed earlier in this paper, ${ }^{309}$ the evidential link between food marketing and obesity is tenuous. This concern is therefore further developed when considering whether the benefits of a ban on the advertising of unhealthy foods and beverages to children are proportionate with its effects upon free expression.

4 Does the limiting measure impair the right or freedom no more than is reasonably necessary for the achievement of its purpose?

The minimal impairment analysis requires the approach taken to fall "within a range of reasonable alternatives." 310 In $R v$ Hansen, McGrath $\mathrm{J}$ considered the question to be "whether there was an alternative but less intrusive means of addressing the legislature's objective which would have a similar level of effectiveness." ${ }^{311}$ In the context of a public health approach to addressing children's food and beverage marketing, Roberto suggests three possible alternatives: industry self-regulation, government policies mandating reduced children's marketing and counter-advertising strategies to educate and defend children from unhealthy food marketing. ${ }^{312}$ The question therefore becomes whether the suggested alternatives represent reasonable alternatives capable of ameliorating advertising's harmful effects with a similar level of effectiveness.

New Zealand's existing system illustrates why self-regulation cannot be considered a reasonable alternative to government-imposed advertising restrictions. An absence of quantitative evidence means the effectiveness of self-regulation in New Zealand cannot be objectively assessed. ${ }^{313}$ The difficulty in comparing approaches is exacerbated by the fact

\footnotetext{
${ }^{309}$ See Part II.

${ }^{310}$ Child Poverty Action Group Inc v Attorney-General [2013] NZCA 402, [2013] 3 NZLR 729 at [102].

${ }^{311} R v$ Hansen, above n 290, at [217] per McGrath J.

312 Christina A Roberto "Counter-advertising to combat unhealthy food marketing will not be enough commentary on 'Can counter-advertising reduce pre-adolescent children's susceptibility to front-of-package promotions on unhealthy foods? Experimental Research"” (2014) 116 Social Science \& Medicine 220 at 220.

${ }^{313}$ See Gorton, above n 5, at 5.
} 
that no other system has yet been tried. Nonetheless, a number of the system's features invite comment. In particular, the system's scope provides ample opportunities for children's exposure to unhealthy food and beverage advertising. The ASA's existing codes do not contain scheduling restrictions for advertisements targeting children or which are broadcast during children's programming. Moreover, the scheduling restrictions in place for FTA broadcasters under the ThinkTV Code are arbitrary and narrow in their application. Restrictions are applied during a narrow band of morning and afternoon programming ending no later than $5 \mathrm{pm} .{ }^{314}$ This overlooks the fact that children form a substantial proportion of television viewership during adult airtime. Research in 2008 suggested that the median bedtime for children aged 6-8 was $7.30 \mathrm{pm}$. ${ }^{315}$ These numbers were even greater for older children, with children aged 9-11 exhibiting a median bedtime of 8.30 pm or later. ${ }^{316}$ This suggests that children are likely to remain exposed to significant quantities of unhealthy food advertising during adults' programming.

Advertising broadcast during school-age children's programming is also subject to nutritional pre-screening. However, the nutritional guidelines applied to advertising remain sufficiently ambiguous to limit their effectiveness in reducing the volume of unhealthy food advertisements. ${ }^{317}$ The absence of external input regarding the application of these health guidelines has resulted in an approach that is ill informed by public health considerations. These problems are compounded by the fact that scheduling restrictions and the associated pre-screening of children's food advertisements are only applied across two FTA television channels. ${ }^{318}$ The high viewership of subscription broadcasting within New Zealand therefore indicates the limited impact that these voluntary restrictions are likely to have upon children's exposure levels. ${ }^{319}$

\footnotetext{
${ }^{314}$ See ThinkTV, above $\mathrm{n} 193$, at 1.

315 Broadcasting Standards Authority "Seen and Heard: Children's Media Use, Exposure, and Response" (May 2008) <www.bsa.govt.nz> at 49.

${ }^{316}$ Broadcasting Standards Authority, above n 315, at 49.

${ }^{317}$ See generally Jennifer L Harris and others "Redefining 'Child-Directed Advertising' to Reduce Unhealthy Television Food Advertising” (2013) 44(4) Am J Prev Med 358 at 359.

${ }^{318}$ See ThinkTV, above n 193, at 1.

${ }^{319}$ See Trisha Dunleavy and Hester Joyce New Zealand Film \& Television: Institution, Industry and Cultural Change (Intellect, Bristol, 2011) at 186-187.
} 
The system's deficiencies are further reinforced by inherent issues in its monitoring and enforcement. The ASA's current complaints system is considered highly reactive, given its reliance upon public complaint before action is taken to remove an advertisement. ${ }^{320}$ The time taken to consider a complaint also results in an advertisement's effects being felt for a considerable period before its withdrawal. ${ }^{321}$ With no penalties for non-compliance, this reactive approach thereby facilitates a permissive advertising environment in which advertisers are repeatedly encouraged to test the system's limits. ${ }^{322}$

The inadequacies of the existing self-regulatory framework also speak to the wider incompatibility of self-regulation with the achievement of public health objectives. Industry groups face limited incentives to regulate advertising according to a public health approach. These misaligned incentives result in a misplaced focus upon advertising's content and not its effects. ${ }^{323}$ Hawkes describes this phenomenon as "enlightened selfinterest," 324 whereby self-regulation purports to control misleading or offensive marketing in order to justify its continued existence. ${ }^{325}$ This approach ignores the fact that the cumulative effects of advertising are more impactful than individually misleading advertisements. ${ }^{326}$ The mere presence of unhealthy children's advertising may pose a threat to children's health. The profit motives of advertisers and food manufacturers underscore the fundamental inconsistency between self-regulation and public health objectives. Market competition requires advertisers to continually stretch boundaries in attempts to stimulate demand for their products. ${ }^{327}$ Advertisers consequently face diminished incentives to regulate advertising without the threat of government regulation. ${ }^{328}$ If industry

\footnotetext{
${ }^{320}$ See New Zealand Medical Association, above n 12, at 17.

${ }^{321}$ See Obesity Action Coalition, above n 252, at 14.

322 See Obesity Action Coalition, above n 252, at 14. See generally Andrew G Parsons and Christoph Schumacher "Advertising regulation and market drivers" (2012) 46(11) European Journal of Marketing 1539 at 1541.

${ }^{323}$ Belinda Reeve "Private Governance, Public Purpose? Assessing Transparency and Accountability in SelfRegulation of Food Advertising to Children” (2013) 10(2) Journal of Bioethical Inquiry 149 at 150.

324 Hawkes, above n 206, at 374.

325 See Hawkes, above n 206, at 380.

${ }^{326}$ See Hawkes, above n 206, at 380.

327 See Parsons and Schumacher, above n 322, at 1542.

${ }^{328}$ See Moodie and others, above n 58, at 676.
} 
self-regulation is viewed as a means of avoiding external intervention, ${ }^{329}$ the New Zealand Government's continued refusal to regulate food and beverage advertising has wholly deprived advertisers of the incentive to self-regulate effectively.

These limitations suggest a number of reasons why a self-regulatory approach to advertising is ill suited to the achievement of public health objectives. To the extent that self-regulation has remained the preferred option for legislators, this suggests its existence is founded more upon economic and legal considerations than reasons of social policy. ${ }^{330}$ Industry representatives continually stress that self-regulation's effectiveness in limiting the harms caused by unhealthy food and beverage advertising is evident from critics' inability to objectively prove otherwise. However, the conceptual incompatibility of a selfregulatory approach with the object of reducing children's advertising exposure demonstrates that self-regulation is not a reasonable alternative to government restrictions upon unhealthy food advertising.

The food and advertising industries have also suggested the use of counter-advertising as an alternative to government-enforced restrictions. This counter-advertising can take a number of forms, with product labelling and proactive social marketing suggested as two means of educating children with regard to advertising and nutrition. Some commentators have suggested that such strategies are more successful in reducing advertising's impact than attempts to control advertising itself. ${ }^{331}$ Notwithstanding its supporters, however, there remain numerous issues with a counter-advertising approach.

The success of counter-advertising initiatives is heavily dependent upon children's comprehension. Though evidence suggests healthful marketing communications have positive effects upon children's nutritional behaviours, ${ }^{332}$ these effects are moderated by

\footnotetext{
${ }^{329}$ See Hawkes, above n 10, at 1968; and Lisa L Sharma, Stephen P Teret and Kelly D Brownell "The Food Industry and Self-Regulation: Standards to Promote Success and to Avoid Public Health Failures" (2010) 100(2) American Journal of Public Health 240 at 245.

330 See Gorton, above n 5, at 5.

331 See Buijzen, Schuurman and Bomhof, above n 46, at 237.

${ }^{332}$ See Roberto, above n 312, at 221.
} 
children's media literacy. ${ }^{333}$ Where children are incapable of interpreting anti-obesity messages, messages' effects upon consumption are markedly negative. ${ }^{334}$ Given the accepted limitations upon children's media literacy, this evidence supports the imposition of statutory advertising restrictions in lieu of social marketing efforts. Similar limitations exist in relation to product labelling. Whilst nutritional labelling is suggested to inform healthier consumer choices, this overstates consumers' ability to utilise this information. Market research demonstrates that Māori, Pacific Islanders and lower socioeconomic groups rarely utilise nutritional product labelling. ${ }^{335}$ Given obesity is disproportionately reflected within these demographics, ${ }^{336}$ a counter-advertising approach is likely to be discriminatory and inconsistent in its effects. The differing cultural perspectives of Māori and Pacific Island groups also explain the unique nature of the New Zealand regulatory environment. Whilst an exposition of the cultural factors underlying regulation is beyond the scope of this paper, the communal approach of Māori and Pacific cultures to social issues suggests government-led regulation is necessary to collectively manage obesity concerns.

These conclusions are confirmed by the fact that counter-advertising has proven only to be effective above a threshold level. ${ }^{337}$ Given the vast disparity in expenditure upon social marketing initiatives and unhealthy product advertising, the success of social-marketing measures is likely to be limited. ${ }^{338}$ To increase children's exposure to more healthful messages would therefore require an uncongenial level of government expenditure. Conversely, existing research illustrates that advertising restrictions represent the most cost-effective means of reducing the harms caused by children's exposure to unhealthy food advertisements. ${ }^{339}$ Logic also suggests that an upstream approach targeting the obesity

\footnotetext{
333 See Dixon and others, above n 21, at 216-217.

${ }^{334}$ See Dixon and others, above n 21, at 218.

${ }^{335}$ Ministry of Health, above n 188, at 95.

336 See Part II.

${ }^{337}$ Rumevichientong and others, above n 53, at 60.

${ }^{338}$ Rumevichientong and others, above n 53, at 60.

339 See A Magnus and others "The cost-effectiveness of removing television advertising of high-fat and/or high-sugar food and beverages to Australian children” (2009) 33(10) International Journal of Obesity 1094.
} 
environment is more appropriate than palliative measures to reduce advertising's effects at an individual level.

The costs and limited effectiveness of a counter-advertising approach demonstrate that it is not a reasonable alternative to an outright ban on the advertising of unhealthy food to children. Given the issues with both self-regulation and counter-advertising, the recommended ban should therefore be seen as the minimally impairing alternative necessary to successfully reduce the effects of children's exposure to unhealthy food and beverage advertising.

\section{Is the limit in due proportion to the importance of the objective?}

In assessing the proportionality of the limit, "the balance to be struck is between social advantage and harm to the right." 340 The key question is therefore whether the benefits conferred by the limit outweigh its deleterious effects. ${ }^{341}$ The Court of Appeal in Minister of Health $v$ Atkinson considered that this analysis involves affording a degree of latitude to Parliament, particularly in areas of social and economic policy. ${ }^{342}$ This is suggested to create a spectrum ranging from matters involving "major political, social or economic decisions ... to matters which have a substantial legal content". ${ }^{343}$ When considering the current context it is therefore appropriate to allow Parliament some leeway to regulate in the face of evidential uncertainty. Notwithstanding this, there remain a number of concerns relating to whether, in spite of the discretion afforded Parliament, a statutory ban on the advertising of unhealthy foods to children represents a proportional limit upon free expression.

This paper has previously suggested that the tenuous connection between food marketing and obesity brings into question the efficacy of measures attempting to limit children's

\footnotetext{
${ }^{340} R v$ Hansen, above $\mathrm{n}$ 290, at [134] per Tipping J.

341 Child Poverty Action Group, above n 310, at [130].

${ }^{342}$ Minister of Health $v$ Atkinson [2012] NZCA 184, [2012] 3 NZLR 456 at [172].

${ }^{343} R v$ Hansen, above n 290, at [116] per Tipping J.
} 
exposure to unhealthy food advertising. ${ }^{344}$ Though a rational connection exists between the suggested ban and its stated object of reducing children's exposure to unhealthy food and beverage advertisements, the potential futility of the law's wider objective suggests the ban's effect upon freedom of expression is disproportionate. In this respect, opponents of a ban may highlight the Canadian Supreme Court's previous rejection of advertising restrictions on the grounds of evidential uncertainty. In RJR-MacDonald Inc $v$ Canada (Attorney General), the Court considered that the absence of a direct link between tobacco consumption and the advertising of tobacco in certain contexts precluded the imposition of a wholesale ban on tobacco advertising. ${ }^{345}$ Though similar evidential uncertainty exists in the context of food and beverage advertising, the ability to analogise with tobacco regulations is limited. Firstly, the decision in RJR-MacDonald appears predominantly motivated by the Canadian legislature's arbitrariness and its failure to present evidence in support of the suggested ban. ${ }^{346}$ Moreover, the imposition of a similar ban on tobacco advertising in New Zealand has been upheld as being proportionate with its stated objective of reducing the harms associated with tobacco marketing. ${ }^{347}$

The nature of the obesity epidemic is also sufficiently unique to reject an analogy with tobacco advertising for the purposes of defining the evidence necessary to justify regulation. Unlike tobacco consumption, which is an easily measured behaviour, the prevalence of obesity is mediated by a complex network of factors. ${ }^{348}$ Consequently, the lack of a direct link between food promotions and obesity should not be considered fatal to the case for government regulation. Rather than demonstrating the ineffectiveness of marketing restrictions, the absence of a direct link to obesity underscores the importance of an integrated approach to obesity-related policy. As previously outlined, a degree of legislative leeway is appropriate in circumstances where the decision-maker is forced to

\footnotetext{
344 See Part II.

${ }^{345}$ RJR-MacDonald, above n 75, at [158]-[159] per McLachlin J.

346 See the Canadian Supreme Court's discussion at [160]-[167].

347 See Rothmans, above n 164, at 360.

348 See Sherry L Emery and others "Public Health Obesity-Related TV Advertising: Lessons Learned from Tobacco" (2007) 33(4) Am J Prev Med 1 at 6. See generally Egger and Swinburn, above n 18, at 477-479.
} 
engage with a range of complex social and economic considerations. ${ }^{349}$ In such cases, decisions must inevitably be reached on the basis of evidential uncertainty. ${ }^{350}$ It is the legislature's accountability to its constituency that vindicates this broader discretion. ${ }^{351}$ This argument is consistent with a precautionary approach to public health policy. ${ }^{352}$ The exigencies of public health policy should enable legislators to curtail individual interests in pursuit of a broader social object. In circumstances where the legislature is forced to rely upon uncertain evidence in regulating to contain the threat of a public health epidemic, the New Zealand Bill of Rights Act should not be used to chill the development of policy consistent with the public interest.

Opponents of the ban are also likely to consider its effectiveness across and within media as illustrative of its limited practical benefits. Prospective advertising restrictions have sparked criticism due their perceived futility. Commentators suggest that marketers' efforts will simply become redirected towards non-traditional media beyond the scope of regulation. ${ }^{353}$ Existing figures already evidence a reorientation of marketing efforts towards non-traditional elements of the promotions mix, such as sponsorship and in-store promotions. ${ }^{354}$ Though the suggested ban applies to a range of media, its coverage is not exhaustive. There consequently remain opportunities for marketers to exploit these gaps and to expose children to unhealthy product advertising. International examples of statutory advertising restrictions also illustrate that extra-territorial broadcasting may significantly undermine restrictions' efficacy. ${ }^{355}$ However, this is not a problem for regulations in New

\footnotetext{
${ }^{349}$ Minister of Health $v$ Atkinson, above $\mathrm{n} 342$, at [172].

${ }^{350}$ Irwin Toy, above n 72, at [80].

${ }^{351}$ Irwin Toy, above $\mathrm{n} 72$, at [80].

${ }^{352}$ See Moodie and others, above n 58, at 676. See generally Deborah Peterson "Precaution: principles and practice in Australian environmental and natural resource management" (speech to the 50th Annual Australian Agricultural and Resource Economics Society Conference, Manly, New South Wales, 8 February 2006).

${ }^{353}$ See Eagle and de Bruin, above n 25, at 263; and Wilde, above n 32, at 161.

${ }^{354}$ See S Galbraith-Emami and T Lobstein "The impact of initiatives to limit the advertising of food and beverage products to children: a systematic review" (2013) 14 Obesity Review 960 at 971; and Mary-Ann Carter and others "Food, fizzy and football: promoting unhealthy food and beverages through sport - a New Zealand case study" (2013) 13 BMC Public Health 126.

${ }^{355}$ See Part V.
} 
Zealand. Given the geographical distance separating New Zealand from other territories, all programming must be rebroadcast domestically. ${ }^{356}$ As a result, broadcasting regulations may be applied to all programming without being undermined by extra-territorial transmissions. This therefore negates one of the key flaws exhibited by other international regulatory frameworks. This advantage may be nullified, however, by New Zealand's continued attempts to develop trade relations with other countries and the resultant concessions likely to be made regarding advertising and intellectual property laws. In particular, though the on-going negotiations surrounding the Trans-Pacific Partnership Agreement remain secret, the agreement is expected to contain provisions restricting New Zealand's ability to regulate the advertising of certain products. ${ }^{357}$ These concessions may thus impair the efficacy of a potential advertising ban in a manner that renders its effect upon freedom of expression disproportionate to the benefits it confers.

Though concerns exist over the potentially limited benefits of the suggested ban, these are mitigated by the ban's limited effect upon the right to freedom of expression. The proposed ban is tailored specifically to the harm caused by children's vulnerability to food and beverage advertising. This is reflected in a focus upon advertisements for unhealthy foods and beverages either targeted at children or broadcast during children's programming. Some adults may be incidentally prevented from viewing advertisements in circumstances where children's advertising is broadcast during adult airtime. However, these effects are ancillary to the ban's true focus upon children's advertising. The ban generally respects adults' freedom of expression and their right to make choices on the basis of the information available to them. Though Parliament must respect the constitutional protection afforded commercial expression, ${ }^{358}$ there exists limited justification for its protection in the context of children's food advertising. Children's accepted vulnerability to advertising undermines the argument for protection on the basis of receivers' rights to information. Moreover, article 13 of the United Nations Convention on the Rights of the

\footnotetext{
356 Email from Peter Agnew (Senior Policy Advisor at the Ministry for Culture and Heritage) to Matthew Mazenier regarding New Zealand television broadcasting (12 September 2014).

357 Jane Kelsey "The Trans-Pacific Partnership Agreement: A Gold-Plated Gift to the Global Tobacco Industry?" (2013) 39 AJLM 237 at 244.

${ }^{358}$ See RJR-MacDonald, above n 75, at [170] per McLachlin J.
} 
Child specifically contemplates the restriction of children's freedom of expression in the interests of public health. ${ }^{359}$ In such circumstances, the protection of advertising does not comport with the traditional justifications for free speech. ${ }^{360}$ In light of these considerations, the limit's effect upon the right of free expression in this context is minimal.

Conversely, it may be suggested that adults' continued exposure to unhealthy food and beverage advertising undermines the limit's effectiveness and results in the disproportionate restriction of free expression. Some commentators believe the case for a ban on children's advertising is weakened by parents' influence upon children's nutrition. ${ }^{361}$ Children's consumption is accordingly moderated by parents acting within a 'gatekeeper' capacity. ${ }^{362}$ As a result, restrictions focusing solely upon children's marketing are suggested to have a limited impact upon obesity. However, this dissenting view overlooks the growing influence of children within modern households. The increasingly distant nature of modern familial structures has led children to wield a substantial degree of market power, both directly as consumers and indirectly through pester power. ${ }^{363}$ Children may thus exert a disproportionate influence on household purchases. Moreover, the dissenting view fails to appreciate the role played by advertising in developing children's food-related preferences and behaviours. ${ }^{364}$ These preferences become manifest in the consumption decisions of young consumers as they become independent. This future market potential is clearly apparent to advertisers. The non-recognition of advertising's continuing effects therefore understates the harm mitigated by an advertising ban in reducing children's exposure to unhealthy food advertisements.

\footnotetext{
${ }^{359}$ United Nations Convention on the Rights of the Child 1577 UNTS 3 (opened for signature 20 November 1989, entered into force 2 September 1990), art 13(2)(b).

360 See Part III.

361 See Chou, Rashad and Grossman, above n 2, at 617.

362 See Cairns, Angus and Hastings, above n 33, at 26.

${ }^{363}$ See Lindstrom, above n 30, at 216.

364 See Part II.
} 


\section{Summarising the case for justification}

Regardless of its critics, a ban on the advertising of unhealthy food and beverages to children is demonstrably justifiable. The tenuous evidence connecting food and beverage advertising to obesity suggests that the reduction in children's advertising exposure effected by the ban would confer little practical benefit. This argument is reinforced by the ban's limited coverage of non-traditional media. Notwithstanding this, the argument in favour of the ban's justification remains strong. Children's vulnerability to advertising and the externalities imposed by obesity underscore the ban's importance. Its focus upon children's food and beverage advertising is also directly connected to the objective of reducing children's exposure to food and beverage advertising. The inadequacies of the existing self-regulatory approach and the questionable effectiveness of counter-advertising measures demonstrate the ban's appropriateness.

Whether the ban is considered proportional will ultimately turn on its form. Though the proportionality of the ban's effect upon free expression is questionable, its limited focus upon the advertising of unhealthy foods and beverages to children substantially preserves both adults' and children's rights to receive information. On the current evidence, an indiscriminate ban on all unhealthy food and beverage advertising would be demonstrably disproportionate to the benefits derived from preserving adults' expression. Whilst accepting this fact, this paper advances that narrower restrictions upon children's advertising are justified given their particular vulnerability to food promotions. However, in the event that such restrictions are considered disproportionate, a less restrictive ban may ultimately prove more politically palatable.

\section{Conclusion}

Obesity poses significant problems for New Zealand society. Children's vulnerability to food promotions and the possible link between advertising and obesity underscore the need for stronger government anti-obesity policy. Nevertheless, questions remain over the constitutionality of advertising restrictions given their impingement upon free expression. This paper has shown that the theoretical justifications underlying the protection of 
commercial expression result in a lower level of constitutional protection. While this provides greater scope for government intervention, New Zealand's existing approach to advertising regulation has been industry-led. International attempts to impose statutory restrictions prove that the government's stance on this issue should be more proactive. Moreover, a s 5 analysis illustrates that a ban on the advertising of unhealthy foods and beverages to children could be implemented consistently with the right to free expression under the New Zealand Bill of Rights Act 1990.

Despite these conclusions, the realpolitik of public health policy must inevitably temper calls for regulatory reform. The limited development of advertising regulations to date suggests that future developments remain contingent upon the interests of key stakeholders. ${ }^{365}$ Existing regulations have reflected stakeholders' concern for advertising that is misleading and unethical in its approach. ${ }^{366}$ Given the importance of prevailing public opinion, ${ }^{367}$ it is not until there is social acceptance for stronger advertising regulations that the necessary change will occur. Oliver thus suggests that evidence alone will be insufficient to inspire government prioritisation of this issue. ${ }^{368}$ Rather, unhealthy food advertising "must be especially salient to important constituencies in order to overcome public ambivalence about governmental intervention into what are ordinarily private affairs." 369

Even with political acceptance, the need for a more cooperative approach to regulation is clear. The WHO has suggested that states must integrate their advertising regulations in order to ensure more comprehensive coverage. ${ }^{370}$ In the absence of cooperation, the effectiveness of independent attempts by national governments to restrict unhealthy food advertising is likely to be minimal. ${ }^{371}$ Furthermore, the suggested advertising ban is not

\footnotetext{
365 See Hawkes, above n 10, at 1969-1970.

366 See Hawkes, above n 10, at 1970.

367 See Bridget Kelly and others "Television Food Advertising to Children: the Extent and Nature of Exposure" (2007) 10(11) Public Health Nutrition 1234 at 1239.

368 See Oliver, above n 304, at 198.

369 See Oliver, above n 304, at 198.

370 World Health Organisation, above n 9, at 5.

371 See Caraher, Landon and Dalmeny, above n 243, at 604.
} 
advanced as a panacea to the obesity epidemic. The evidence base has repeatedly underscored the multifaceted and dynamic nature of the obesity problem. However, change has to start somewhere. As one of the more easily controlled factors moderating the obesity epidemic, the implementation of marketing restrictions constitutes an important first step. The equivocal evidence of a link between food marketing and obesity demonstrates the potential for proactive government intervention to rebalance the obesity environment.

If the current self-regulatory regime in New Zealand is seen as an experiment to help inform the future development of government policy, this experiment can be considered a failure. The theoretical incompatibility of industry self-regulation with a public health approach reveals the New Zealand Government's misplaced faith in the self-regulation of advertising. Though political realities will ultimately be determinative of the government's response to the obesity epidemic, the fact remains that the current system is unsuited to reducing children's harmful exposure to unhealthy food and beverage advertising. Given children's accepted vulnerability to advertising and the increasing social costs of obesity, the time has come to consider a ban on the advertising of unhealthy food and beverages to children as a justified means of battling the bulge. 


\section{Bibliography}

\section{A Legislation}

1 New Zealand

Companies Act 1993.

Consumer Guarantees Act 1993.

Fair Trading Act 1986.

Financial Markets Conduct Act 2013.

New Zealand Bill of Rights Act 1990.

Sale and Supply of Alcohol Act 2012.

Smoke-free Environments Act 1990.

\section{Canada}

Canadian Charter of Rights and Freedoms (Part 1 of Constitution Act) 1982 RS C c-11.

Quebec Consumer Protection Act 1978 RS Q c P-40.1.

Tobacco Products Control Act SC 1998 c 20.

\section{United Kingdom}

Communications Act 2003 (UK).

The Contracting Out (Functions relating to Broadcast Advertising) and Specification of Relevant Functions Order 2004 (UK).

Corporate Manslaughter and Corporate Homicide Act 2007 (UK).

4 Sweden

Marketing Practices Act (Sweden) No 2008:486.

Radio and Television Law (Sweden) No 2010:696.

\section{B Cases}

$1 \quad$ New Zealand

Child Poverty Action Group Inc v Attorney-General [2013] NZCA 402, [2013] 3 NZLR 729.

Director-General of Health $v$ Rothmans of Paul Mall (New Zealand) Ltd [1996] DCR 353 (DC). 
Minister of Health v Atkinson [2012] NZCA 184, [2012] 3 NZLR 456.

Moonen v Film \& Literature Board of Review [2000] 2 NZLR 9 (CA).

$R v$ Hansen [2007] NZSC 7, [2007] 3 NZLR 1.

2 Canada

Canada (Attorney General) v JTI-MacDonald Corp [2007] 2 SCR 610.

Edmonton Journal v Alberta (Attorney General) [1989] 2 SCR 1326.

Ford v Quebec (Attorney General) [1988] 2 SCR 712.

Irwin Toy v Quebec (Attorney General) [1989] 1 SCR 927.

Re Klein and Law Society of Upper Canada (1985) 16 DLR (4 $\left.{ }^{\text {th }}\right) 489$.

RJR-MacDonald Inc v Canada (Attorney General) [1995] 3 SCR 199.

Rocket v Royal College of Dental Surgeons (Ontario) [1990] 2 SCR 232.

$R$ v Oakes [1986] 1 SCR 103.

3 European Union

Markt Intern \& Beerman v Germany (1990) 12 EHRR 161.

4 United States

Abrams $v$ United States 250 US 616 (1919).

Central Hudson Gas \& Electric Corp v Public Service Commission of New York 447 US 557 (1980).

Nike Inc v Kasky 539 US 654123 (2003).

Pittsburgh Press Co v Pittsburgh Commission on Human Relations 413 US 376 (1973).

Posadas de Puerto Rico Associates v Tourism Company of Puerto Rico 478 US 328 (1986).

United States v Edge Broadcasting Company 509 US 418 (1993).

Valentine v Chrestensen 316 US 52 (1942).

Virginia State Board of Pharmacy v Virginia Citizens Consumer Council Inc 425 US 748 (1976).

Whitney v California 274 US 357 (1927).

44 Liquormart Inc v Rhode Island 517 US 484 (1996). 


\section{European Materials}

1 European Union Legislation

Directive 2005/29/EC of the European Parliament and of the Council of 11 May 2005 concerning unfair business-to-consumer commercial practices in the internal market and amending Council Directive 84/450/EEC, Directives 97/7/EC, 98/27/EC and 2002/65/EC of the European Parliament and of the Council and Regulation (EC) No 2006/2004 of the European Parliament and of the Council [2005] OJ L 149/22.

Directive 2007/65/EC of the European Parliament and of the Council of 11 December 2007 amending Council Directive 89/552/EEC on the coordination of certain provisions laid down by law, regulation or administrative action in Member States concerning the pursuit of television broadcasting activities [2007] OJ L 332/27.

Directive 2010/13/EU of the European Parliament and of the Council of 10 March 2010 on the coordination of certain provisions laid down by law, regulation or administrative action in Member States concerning the provision of audiovisual media services [2010] OJ L 95/1.

2 European Union Cases

Case C-34/95 Konsumentombudsmannen (KO) v De Agostini (Svenska) Förlag AB [1997] ECR I-3843.

\section{International Materials}

North American Free Trade Agreement 32 ILM 289 (signed 17 December 1992, entered into force 1 January 1994).

United Nations Convention on the Rights of the Child 1577 UNTS 3 (opened for signature 20 November 1989, entered into force 2 September 1990).

\section{E Books and Chapters in Books}

Eric Barendt Freedom of Speech (2 ${ }^{\text {nd }}$ ed, Oxford University Press, Oxford, 2009).

RN Bolton "Modelling the impact of television food advertising on children's diets" in JH Leigh and CR Martin (eds) Current Issues and Research in Advertising (University of Michigan, Ann Arbor (MI), 1983) 173.

Andrew Butler and Petra Butler The New Zealand Bill of Rights Act: A Commentary (LexisNexis, Wellington, 2005). 
Ian Cram Contested Words: Legal Restrictions on Freedom of Speech in Liberal Democracies (Ashgate, Aldershot (UK), 2006).

Greg Critser Fat Land: How Americans Became the Fattest People in the World (Penguin Books, New York, 2003).

Trisha Dunleavy and Hester Joyce New Zealand Film \& Television: Institution, Industry and Cultural Change (Intellect, Bristol, 2011).

Thomas I Emerson The System of Freedom of Expression (Random House, New York, 1970).

Susy Frankel "New Zealand: Regulation of Tobacco, Alcohol and Unhealthy Food in New Zealand and Coordinating the Trans-Tasman Relationship" in Tania Voon, Andrew D Mitchell and Jonathan Liberman (eds) Regulating Tobacco, Alcohol and Unhealthy Foods: The Legal Issues (Routledge, Oxford, 2014) 296.

Martin Lindstrom BRANDchild (Kogan Page, London, 2003).

Roger A Shiner Freedom of Commercial Expression (Oxford University Press, Oxford, 2003).

\section{F Journal Articles}

Jean Adams and others "Effect of Restrictions on Television Food Advertising to Children on Exposure to Advertisements for 'Less Healthy' Foods: Repeat Cross-Sectional Study" (2012) 7(2) PLOS One 1.

David Ashton "Food advertising and childhood obesity" (2004) 97(2) Journal of the Royal Society of Medicine 51.

C Edwin Baker "Commercial Speech: A Problem in the Theory of Freedom" (1976) 62 Iowa L Rev 1.

Ulf Bernitz "Consumer Protection: Aims, Methods, and Trends in Swedish Consumer Law” (1976) 20 Sc St L 12.

M Neil Browne, Lauren Frances Biksacky and Alex Frondorf “Advertising to Children and the Commercial Speech Doctrine: Political and Constitutional Limits" (2009) 58 Drake L Rev 67.

Moniek Buijzen, Joris Schuurman and Elise Bomhof “Associations between children's television advertising exposure and their food consumption patterns: A household diarysurvey study" (2008) 50 Appetite 231. 
Martin Caraher, Jane Landon and Kath Dalmeny "Television Advertising and Children: Lessons from Policy Development” (2005) 9(5) Public Health Nutrition 596.

Mary-Ann Carter and others "Food, fizzy and football: promoting unhealthy food and beverages through sport - a New Zealand case study" (2013) 13 BMC Public Health 126.

Shin-Yi Chou, Inas Rashad and Michael Grossman "Fast-Food Restaurant Advertising on Television and its Influence on Childhood Obesity" (2008) 51(4) JLE 599.

WR Clarke and RM Lauer "Does Childhood Obesity Track Into Adulthood" (1993) 33(5) Critical Reviews in Food Science and Nutrition 423.

RH Coase "Advertising and Free Speech" (1977) 6 JLS 1.

Kath Dalmeny "Food marketing: the role of advertising in child health" (2003) 13(1) Consumer Policy Review 2.

Almudena Gonzalez del Valle "A Reflection on European Regulation of Television Advertising to Children" (2013) 32(2) Communication Research Trends 19.

Mercedes de Onis, Monika Blossner and Elaine Borghi "Global prevalence and trends of overweight and obesity among preschool children" (2010) 92(5) American Journal of Clinical Nutrition 1257.

Tirtha Dhar and Kathy Baylis "Fast-Food Consumption and the Ban on Advertising Targeting Children: The Quebec Experience" (2011) 48 Journal of Marketing Research 799.

Aaron Director "The Parity of the Economic Market Place" (1964) 7 JLE 1.

Helen Dixon and others "Can counter-advertising reduce pre-adolescent children's susceptibility to front-of-package promotions on unhealthy foods? Experimental Research" (2014) 116 Social Science \& Medicine 211.

Keith Dubick “Commercial Expression: A 'Second-Class' Freedom?” (1996) 60 Sask L Rev 91.

Lynne Eagle and Anne de Bruin "Advertising Restrictions: Protection of the Young and Vulnerable?" (2001) 2(4) Young Consumers 259.

Garry Egger and Boyd Swinburn "An 'Ecological' Approach to the Obesity Pandemic" (1997) 315(7106) British Medical Journal 477.

Thomas I Emerson "Toward a General Theory of the First Amendment" (1963) 72 YLJ 877. 
Sherry L Emery and others "Public Health Obesity-Related TV Advertising: Lessons Learned from Tobacco" (2007) 33(4) Am J Prev Med 1.

S Galbraith-Emami and T Lobstein "The impact of initiatives to limit the advertising of food and beverage products to children: a systematic review" (2013) 14 Obesity Review 960.

A Garde "Food advertising and obesity prevention: what role for the European Union?" (2008) 31(1) Journal of Consumer Policy 25.

Janny M Goris and others "Television Food Advertising and the Prevalence of Childhood Overweight and Obesity: a Multicountry Comparison" (2009) 13(7) Public Health Nutrition 1003.

Karla K Gower "Looking Northward: Canada's Approach to Commercial Expression" (2005) 10 Comm L \& Pol'y 29.

Jason Halford and others "Television Food Advertising to Children: A Global Perspective" (2010) 100(9) American Journal of Public Health 1730.

Jennifer L Harris, John A Bargh and Kelly D Brownell "Priming Effects of Television Food Advertising on Eating Behaviour” (2009) 28(4) Health Psychology 404.

Jennifer L Harris and others "Redefining 'Child-Directed Advertising' to Reduce Unhealthy Television Food Advertising” (2013) 44(4) Am J Prev Med 358.

Corinna Hawkes "Regulating Food Marketing to Young People Worldwide: Trends and Policy Drivers" (2007) 97(11) American Journal of Public Health 1962.

Corinna Hawkes "Self-regulation of food advertising: what it can, could and cannot do to discourage unhealthy eating habits among children" (2005) 30 British Nutrition Foundation Nutrition Bulletin 374.

Bill Jeffery "The Supreme Court of Canada's Appraisal of the 1980 Ban on Advertising to Children in Quebec: Implications for 'Misleading' Advertising Elsewhere” (2006) 39 Loy LA L Rev 237.

Bridget Kelly and others "Television Food Advertising to Children: the Extent and Nature of Exposure" (2007) 10(11) Public Health Nutrition 1234.

Jane Kelsey "The Trans-Pacific Partnership Agreement: A Gold-Plated Gift to the Global Tobacco Industry?" (2013) 39 AJLM 237.

Monique Potvin Kent, Lise Dubois and Alissa Wanless "A Nutritional Comparison of Foods and Beverages Marketed to Children in Two Advertising Policy Environments" (2012) 20(9) Obesity 1829. 
Alex Kozinski and Stuart Banner "Who’s Afraid of Commercial Speech?” (1990) 76(4) Va L Rev 627.

Sonia Livingstone and Ellen J Helsper "Does Advertising Literacy Mediate the Effects of Advertising on Children? A Critical Examination of Two Linked Research Literatures in Relation to Obesity and Food Choice" (2006) 56(3) Journal of Communication 560.

T Lobstein and S Dibb "Evidence of a possible link between obesogenic food advertising and child overweight" (2005) 6 Obesity Reviews 203.

A Magnus and others "The cost-effectiveness of removing television advertising of highfat and/or high-sugar food and beverages to Australian children" (2009) 33(10) International Journal of Obesity 1094.

Rob Moodie and others "Profits and pandemics: prevention of harmful effects of tobacco, alcohol, and ultra-processed food and drink industries" (2013) 381(9867) Lancet 670.

Maria Morgan and others “A content analysis of children's television advertising: focus on food and oral health" (2008) 12(6) Public Health Nutrition 748.

Colin R Munro “The Value of Commercial Speech” (2003) 62(1) CLJ 134.

Thomas R Oliver “The Politics of Public Health Policy” (2006) 27 Annu Rev Public Health 195.

Andrew G Parsons and Christoph Schumacher "Advertising regulation and market drivers" (2012) 46(11) European Journal of Marketing 1539.

Michael Plogell and Jesper Sundstrom "Advertising to children in Sweden" (2004) 5(2) Advertising \& Marketing to Children 65.

Martin H Redish “The Value of Free Speech” (1982) 130(3) U Pa L Rev 591.

Martin H Redish "Tobacco Advertising and the First Amendment” (1995) 81 Iowa L Rev 589.

Belinda Reeve "Private Governance, Public Purpose? Assessing Transparency and Accountability in Self-Regulation of Food Advertising to Children" (2013) 10(2) Journal of Bioethical Inquiry 149.

Caroline Reid "Freedom of Expression, Commercial Expression and Tobacco in Canada" (2008) 39 VUWLR 343.

Christina A Roberto "Counter-advertising to combat unhealthy food marketing will not be enough commentary on 'Can counter-advertising reduce pre-adolescent children's 
susceptibility to front-of-package promotions on unhealthy foods? Experimental Research"” (2014) 116 Social Science \& Medicine 220.

Pimbucha Rumevichientong and others "The Impact of Food Advertisements on Changing Eating Behaviours: An Experimental Study” (2014) 44 Food Policy 59.

Henry Saffer and Frank Chaloupka "The effect of tobacco advertising bans on tobacco consumption" (2000) 19 Journal of Health Economics 1117.

TM Scanlon "Freedom of Expression and Categories of Expression" (1979) 40 U Pitt L Rev 519.

Lisa L Sharma, Stephen P Teret and Kelly D Brownell "The Food Industry and SelfRegulation: Standards to Promote Success and to Avoid Public Health Failures" (2010) 100(2) American Journal of Public Health 240.

Robert J Sharpe "Commercial Expression and the Charter" (1987) 37(3) UTLJ 229.

S Shiffrin "The First Amendment and Economic Regulation: Away from a General Theory of the First Amendment" (1983) 78 NWULR 1212.

Boyd Swinburn and others "The 'Sydney Principles' for reducing the commercial promotion of foods and beverages to children" (2008) 11(9) Public Health Nutrition 881.

Louise Thornley, Louise Signal and George Thomson "Does industry regulation of food advertising protect child rights?” (2010) 20(1) Critical Public Health 25.

Patti M Valkenburg "Media and Youth Consumerism" (2000) 27 Journal of Adolescent Health 52.

Parke Wilde "Self-regulation and the response to concerns about food and beverage marketing to children in the United States" (2009) 67(3) Nutrition Reviews 155.

Nick Wilson and others "Marketing fat and sugar to children on New Zealand television" (2006) 42 Preventive Medicine 96.

Brian M Young, Anne de Bruin and Lynne Eagle "Attitudes of Parents Toward Advertising to Children in the UK, Sweden and New Zealand" (2003) 19 Journal of Marketing Management 475.

\section{G Reports}

Advertising Standards Authority Final Report on the Review of the Code for Advertising to Children and the Code for Advertising of Food (March 2010).

Sharron Bowers, Louise Signal and Gabrielle Jenkin Does Current Industry SelfRegulation of Food Marketing in New Zealand Protect Children from Exposure to 
Unhealthy Food Advertising? (Otago University Health Promotion and Policy Research Unit, 2012).

Georgina Cairns, Kathryn Angus and Gerard Hastings The Extent, Nature and Effects of Food Promotion to Children: A Review of the Evidence to December 2008 (World Health Organisation, December 2009).

Food and Agriculture Organisation of the United Nations The State of Food and Agriculture (June 2013).

Delvina Gorton Advertising Food to Children: Background Paper (Heart Foundation New Zealand, April 2011).

Gerard Hastings and others Review of Research on the Effects of Food Promotion to Children: Final Report (World Health Organisation, September 2003).

Corinna Hawkes Marketing Food to Children: the Global Regulatory Environment (World Health Organisation, 2004).

Anne Matthews and others The Marketing of Unhealthy Food to Children in Europe: A Report of Phase 1 of the 'Children, Obesity and Associated Avoidable Chronic Diseases' Project (European Health Network, 2005).

Ministry of Health New Zealand Health Survey: Annual Update of Key Findings 2012/13 (December 2013).

New Zealand Medical Association Policy Briefing: Tackling Obesity (May 2014).

Obesity Action Coalition Would you like lies with that? Food, Kids and Advertising (October 2007).

United Kingdom Department of Health Changes in Food and Drink Advertising and Promotion to Children: A Report Outlining the Nature and Balance of Food and Drink Advertising and Promotion to Children (2008).

United Kingdom Food Standards Authority Nutrient Profiling Technical Guidance (April 2009).

United Kingdom Office of Communications Childhood Obesity - Food Advertising in Context (July 2004).

United Kingdom Office of Communications HFSS Advertising Restrictions: Final Review (July 2010).

United Kingdom Office of Communications Television Advertising of Food and Drink Products to Children: Final Statement (February 2007). 
World Health Organisation Population-Based Prevention Strategies for Childhood Obesity: Report of the WHO Forum and Technical Meeting (December 2009).

World Health Organisation Report by the Secretariat on the Prevention and Control of Noncommunicable Diseases: Implementation of the Global Strategy (A63/12, April 2010).

\section{H Dissertations}

Sarah Barker "The Obesity Epidemic: Towards a Regulatory Framework to Combat Obesity in New Zealand" (LLM Dissertation, Victoria University of Wellington, 2011).

\section{Other Sources}

1 Looseleaf texts

Thomas Gault (ed) Gault on Commercial Law (online looseleaf ed, Westlaw NZ).

\section{Internet materials}

Advertising Standards Authority "Advertising Standards Authority Inc" <www.asa.co.nz>.

Advertising Standards Authority "Advertising Standards Complaints Board" <www.asa.co.nz>.

Advertising Standards Authority "The Advertising Standards Authority" <www.asa.co.nz>.

Advertising Standards Authority "Children's Code for Advertising Food" <www.asa.co.nz>.

Advertising Standards Authority "Code for Advertising of Food" <www.asa.co.nz>.

Advertising Standards Authority "Code for Advertising to Children" <www.asa.co.nz>.

Advertising Standards Authority "Decision Process" <www.asa.co.nz>.

Advertising Standards Canada "Broadcast Code for Advertising to Children - The Code" (August 2014) <www.adstandards.com>.

Advertising Standards Canada "The 14 Clauses of the Canadian Code of Advertising Standards" (August 2014) <www.adstandards.com>.

Ben Heather "Obesity epidemic at 'crisis' point" (9 June 2014) Stuff.co.nz <www.stuff.co.nz>.

Broadcast Committee of Advertising Practice "BCAP Code: The UK Code of Broadcast Advertising" (1 September 2010) <http://www.cap.org.uk>. 
Broadcasting Standards Authority "Seen and Heard: Children's Media Use, Exposure, and Response" (May 2008) <www.bsa.govt.nz>.

Canadian Marketing Association "Code of Ethics and Standards of Practice" <www.thecma.org>.

Commerce Commission "Unsubstantiated Representations" (December 2013) <www.comcom.govt.nz>.

Ministry of Health "Food and Nutrition Guidelines to Healthy Children and Young People (Aged 2-18 years): A Background Paper” (2012)<www.health.govt.nz>.

Quebec Office de la Protection du Consommateur "Advertising Directed at Children under 13 Years of Age: Guide to the Application of Sections 248 and 249 Consumer Protection Act" (10 September 2012)<www.opc.gouv.qc.ca>.

ThinkTV “Advertising on Television: Getting it Right for Children” (March 2011) <www.thinktv.co.nz>.

ThinkTV "The Children's Television Policies: Advertising in Pre-School and School-Age Children's Television Programming Times" (March 2011) <www.thinktv.co.nz>.

World Health Organisation "Obesity and Overweight" (March 2013) <www.who.int/mediacentre/>.

\section{Letters and emails}

Email from Peter Agnew (Senior Policy Advisor at the Ministry for Culture and Heritage) to Matthew Mazenier regarding New Zealand television broadcasting (12 September 2014).

\section{Speeches}

Deborah Peterson "Precaution: principles and practice in Australian environmental and natural resource management" (speech to the 50th Annual Australian Agricultural and Resource Economics Society Conference, Manly, New South Wales, 8 February 2006). 